\title{
Animal Models of ANCA Associated Vasculitis
}

\author{
Lani Shochet ${ }^{1,2}$, Stephen Holdsworth ${ }^{1,2,3}$ and A. Richard Kitching 1,2,4* \\ ${ }^{1}$ Centre for Inflammatory Diseases, Monash University Department of Medicine, Monash Medical Centre, Clayton, VIC, \\ Australia, ${ }^{2}$ Department of Nephrology, Monash Health, Clayton, VIC, Australia, ${ }^{3}$ Department of Immunology, Monash Health, \\ Clayton, VIC, Australia, ${ }^{4}$ Department of Pediatric Nephrology, Monash Health, Clayton, VIC, Australia
}

\section{OPEN ACCESS}

Edited by:

Andreas Kronbichler, Innsbruck Medical University, Austria

Reviewed by:

Benjamin Wilde,

University of Duisburg-Essen,

Germany

Akihiro Ishizu,

Hokkaido University, Japan

*Correspondence:

A. Richard Kitching

richard.kitching@monash.edu

Specialty section

This article was submitted to Autoimmune and Autoinflammatory

Disorders,

a section of the journal

Frontiers in Immunology

Received: 03 December 2019

Accepted: 09 March 2020

Published: 09 April 2020

Citation:

Shochet L, Holdsworth S and Kitching AR (2020) Animal Models of

ANCA Associated Vasculitis.

Front. Immunol. 11:525.

doi: 10.3389/fimmu.2020.00525
Anti-neutrophil cytoplasmic antibody (ANCA) associated vasculitis (AAV) is a rare and severe autoimmune multisystemic disease. Its pathogenesis involves multiple arms of the immune system, as well as complex interactions between immune cells and target organs. Experimental animal models of disease can provide the crucial link from human disease to translational research into new therapies. This is particularly true in $\mathrm{AAV}$, due to low disease incidence and substantial disease heterogeneity. Animal models allow for controlled environments in which disease mechanisms can be defined, without the clinical confounders of environmental and lifestyle factors. To date, multiple animal models have been developed, each of which shed light on different disease pathways. Results from animal studies of AAV have played a crucial role in enhancing our understanding of disease mechanisms, and have provided direction toward newer targeted therapies. This review will summarize our understanding of AAV pathogenesis as has been gleaned from currently available animal models, as well as address their strengths and limitations. We will also discuss the potential for current and new animal models to further our understanding of this important condition.

Keywords: autoantibodies, antineutrophil cytoplasmic, animal models, autoimmunity, glomerulonephritis, myeloperoxidase, proteinase 3 , translational medical research

\section{INTRODUCTION}

The anti-neutrophil cytoplasmic antibody (ANCA) associated vasculitides (AAV) are autoimmune diseases characterized by systemic inflammation and subsequent destruction of small to medium blood vessels within target organs, particularly the kidneys and respiratory tract. It is a rare but life-threatening condition, with an incidence of 13-20 people per million per year worldwide, and a peak age of onset of 65-74 years (1). Syndromically, AAV can present as granulomatosis with polyangiitis (GPA; formerly known as Wegener's granulomatosis), microscopic polyangiitis (MPA) or eosinophilic granulomatosis with polyangiitis (EGPA). If untreated, mortality of AAV may be as high as $80 \%$ within 1 year of diagnosis (2). Treatment involves potent immunosuppressive agents that may have significant associated adverse effects, including infection and malignancy. Infection accounts for almost half of the deaths in treated patients in the first year (3). AAV-related glomerulonephritis (GN) is an important cause of end stage kidney disease and commonly defines outcomes in AAV.

$\mathrm{AAV}$ is a largely heterogeneous condition, with substantial variation in clinical presentation and sequelae. This variability presents significant challenges for patients and their doctors, as well as for recruitment and categorization in clinical studies. The hallmark of disease is the presence of autoantibodies targeting proteins within azurophilic (primary) granules of neutrophils, with the two 
most clinically relevant autoantigens being proteinase 3 (PR3) and myeloperoxidase (MPO). These proteins are important players in the antimicrobial activity of neutrophils. AAV can be classified based on syndromic features or on the auto-antigen involved, specifically MPO-AAV or PR3-AAV. The Chapel Hill Consensus guidelines divide AAV into syndromic categories: GPA, MPA, and EGPA (4). The majority of people with GPA or MPA are ANCA positive at diagnosis, but in around $10 \%$ of patients ANCA are not detected in sera by conventional assays. Dual positive PR3-ANCA and MPO-ANCA serology is uncommon. Whilst most patients with GPA are PR3-ANCA positive, and similarly for MPA patients with MPO-ANCA, overlap between the clinical syndrome and ANCA specificity is incomplete. Observational studies have suggested that serological classification may better predict clinical features such as relapse rate (5), renal survival and mortality (6). The concept that PR3$\mathrm{AAV}$ and MPO-AAV are different but related conditions is further supported by the identification of different genetic and epidemiological backgrounds between PR3-AAV and MPO-AAV [reviewed by Cornec et al. (7)].

The pathophysiology of AAV is complex and remains incompletely understood. First, $\mathrm{T}$ and $\mathrm{B}$ cell tolerance to MPO or PR3 is lost, via mechanisms that remain incompletely described (Figure 1). Subsequently, with T cell help, autoreactive

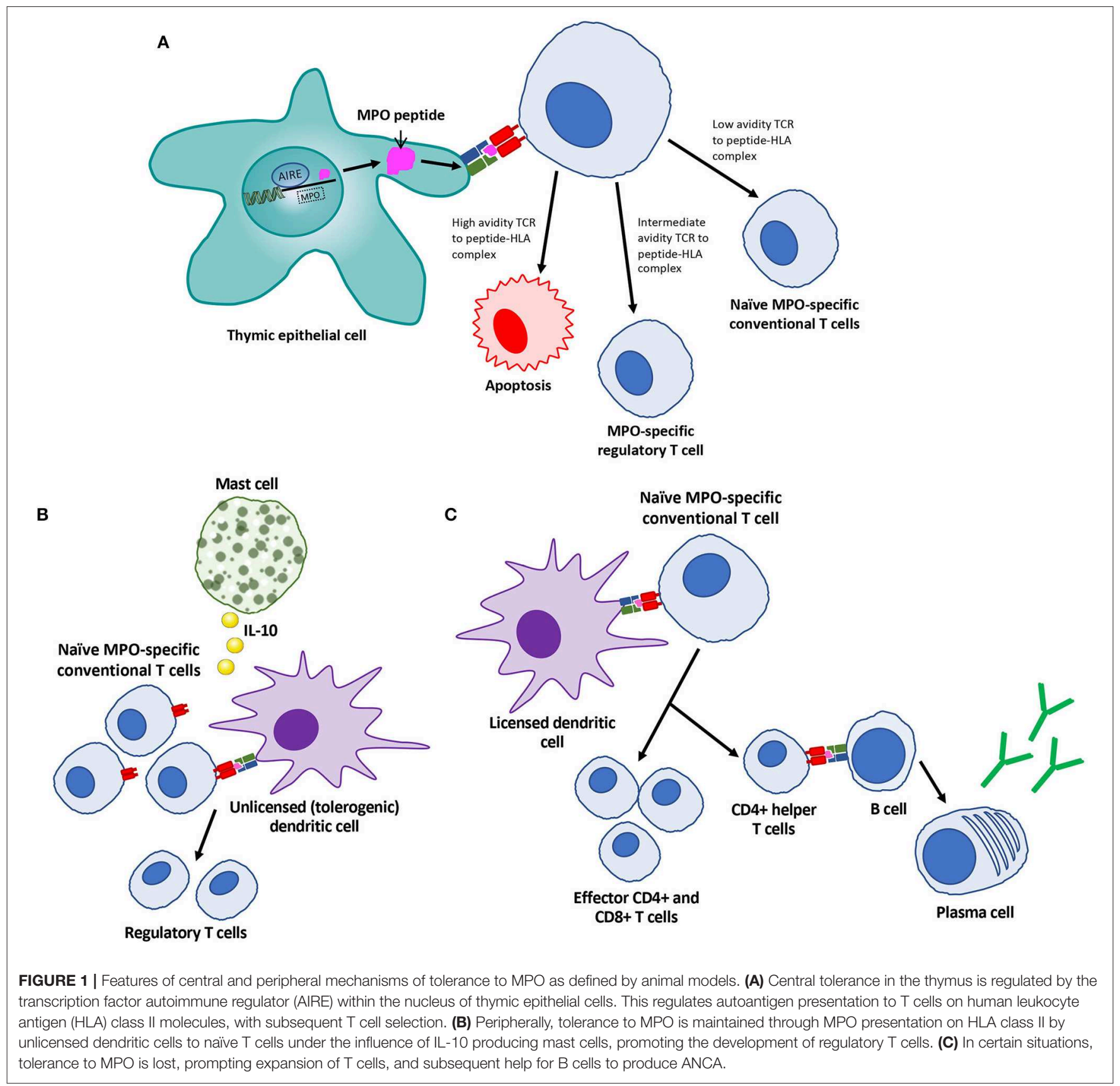


B cells or plasma cells produce ANCA. ANCA activate neutrophils (Figure 2) and induce their adherence to vulnerable microvascular beds, such as the glomerulus, where they degranulate and undergo NETosis, inducing endothelial injury (Figure 3). In this process, ANCA antigens are also deposited in the glomerulus, with the ability to be recognized by effector $\mathrm{T}$ cells, further contributing to injury [reviewed in Hutton et al. (8)]. It is hypothesized that monocyte/macrophages play a role later in disease (9); they themselves can be activated by ANCA and also have the capacity to present antigens to effector T cells (10).

Much of our understanding of the pathophysiology of AAV comes from animal models of disease, coupled with observations in human disease and in vitro studies. For example, since the discovery of ANCA in humans in 1982 (11), in vitro studies during the 1990s demonstrated that ANCA could activate human neutrophils (12-14), with animal studies later confirming the pathogenicity of ANCA in vivo with passive transfer of ANCA into mice (15). Similar advances have been made in understanding the role of effector $\mathrm{T}$ cells (16), complement (17), and the nature of $\mathrm{T}$ and $\mathrm{B}$ cell epitopes (18-20) in the pathogenesis of AAV. Furthermore, the judicious use of animal models has allowed pre-clinical investigation of new targeted therapies, exemplified by work on complement in a model involving the passive transfer of anti-MPO antibodies $(21,22)$. Whilst clinical and in vitro research into PR3-AAV is plentiful, no consistent PR3-AAV animal models currently exist, meaning that the in vivo understanding of AAV pathogenesis is based largely on models of anti-MPO disease. Whilst PR3AAV and MPO-AAV share many pathological and clinical similarities, the differences between them span epidemiology, genetic predisposition, clinical features and histopathology [reviewed by Hilhorst et al. (23)]. Given these differences, it is important that animal models of PR3-AAV are developed, to further our understanding of the complexities of PR3-AAV, the differences between MPO-AAV and PR3-AAV, and to more accurately target treatments.

AAV is a unique autoimmune disease. Its pathogenesis involves all aspects of the immune system, with complex interplay between innate and adaptive immunity. It is one of only a few autoimmune diseases in which a single pathogenic autoantibody is measured. Furthermore, ANCA is pathogenic by binding to neutrophils and monocytes and inducing cellular activation, with resultant microvascular endothelial injury. However, depletion of the autoantibody alone may not be effective in disease control, and disease can be quiescent while the antibody remains detectable, suggesting redundancy in injurious autoimmune pathways.

Animal models of disease allow for a controlled environment, with the consequent ability to thoroughly interrogate human clinical observations and test hypotheses derived from these observations. AAV is a rare disease and consequently human studies often have limited numbers of patients. Patients are often heterogeneous and difficult to compare, due to confounders such as autoantigen specificity and potential epitope spreading throughout the course of disease, diverse clinical manifestations and immunosuppressive treatments. Animal models are also necessary for pre-clinical development of more effective, targeted treatments, before their translation into clinical experimentation. Ultimately though, models are just that: models. Whilst their use is invaluable in scientific research, they are only part of the puzzle of comprehensive understanding of a uniquely human disease.

This review will outline existing models which have contributed to the field of AAV. While many of these models have illuminated the biology of AAV, no single animal model presented here is able to replicate every stage of AAV, from loss of tolerance through to the development of end-organ fibrosis. Furthermore, these models still leave us with significant gaps in our disease understanding, including loss of tolerance,
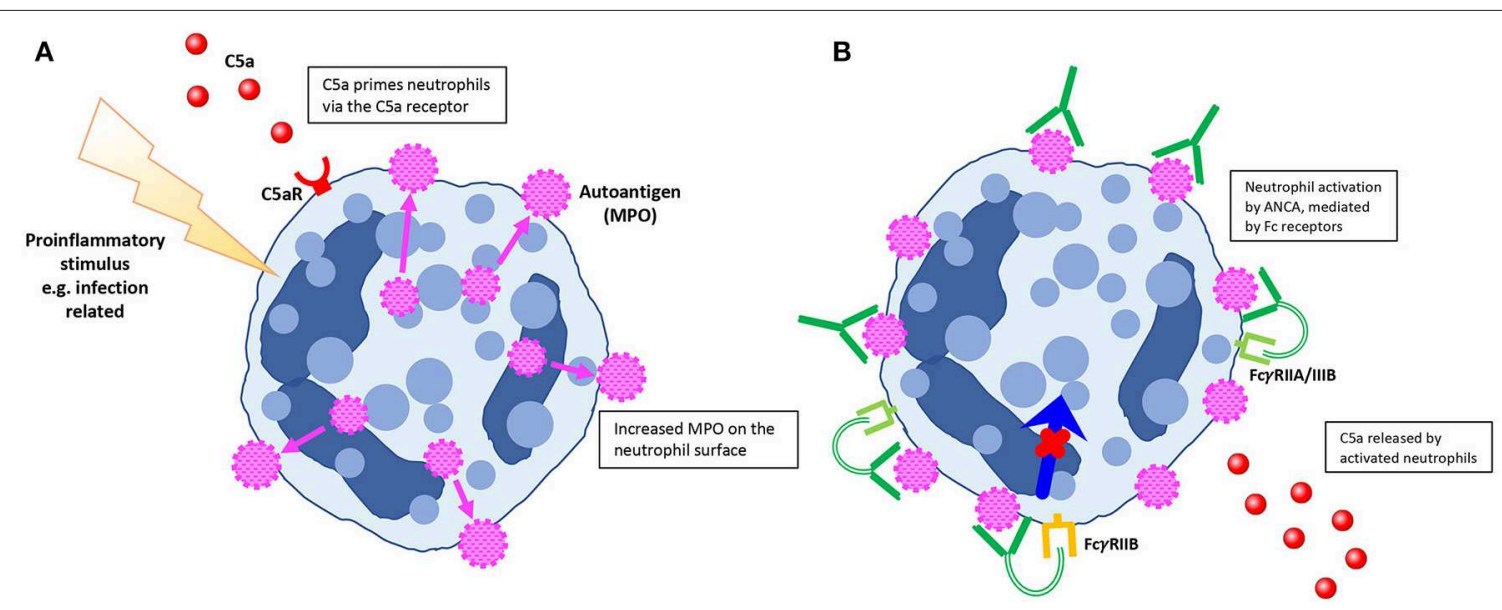

FIGURE 2 | Features of neutrophil priming and activation by ANCA as defined by animal models. (A) Pro-inflammatory stimuli (including lipopolysaccharide and complement factor C5a) cause neutrophil priming, with increased expression of ANCA antigens on the neutrophil surface. (B) Mediated by regulatory Fc $\gamma$ receptors, ANCA have the capacity to activate neutrophils. Neutrophil activation causes release of C5a, with subsequent complement pathway activation as well as further neutrophil priming. 


\section{A}

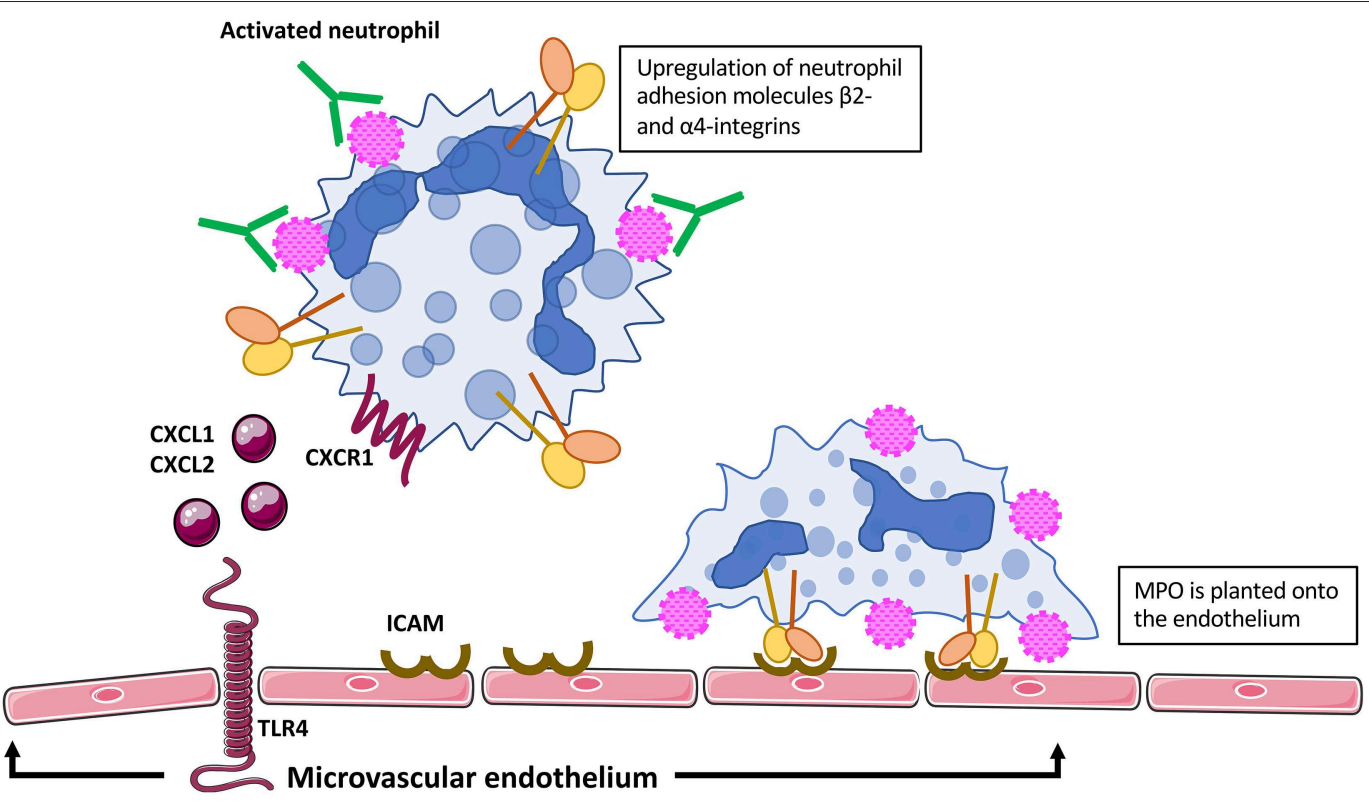

B

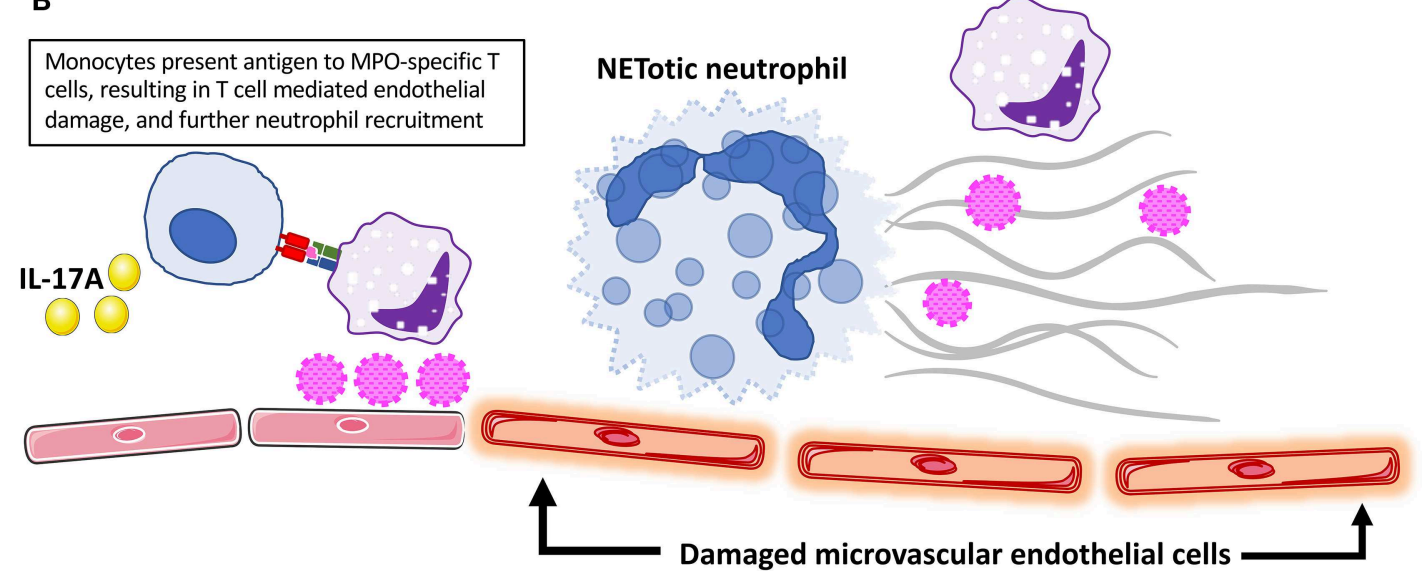

FIGURE 3 | Features of neutrophil migration and adhesion, and endothelial damage as defined by animal models. (A) Activated neutrophils migrate to vulnerable vascular beds, including the glomerulus. The presence of TNF is associated with TLR4 upregulation on glomerular endothelial cells, which contributes to neutrophil migration through production of chemoattractants CXCL1 and CXCL2. After activation by ANCA, neutrophils express $\beta 2$-integrins (LFA-1 and MAC-1), which enhance neutrophil adhesion to the glomerular endothelium. Neutrophil retention within the glomerular capillaries is moderated by the C5a receptor. (B) MPO is planted onto the glomerular endothelium, allowing local recognition by MPO-specific effector T cells and subsequent injury. Circulating monocytes have been shown experimentally to present antigens within glomeruli; however, microvascular endothelial cells and dendritic cells may also be involved in antigen recognition by effector $\mathrm{T}$ cells.

Release of interleukin-17A (IL-17A) by T cells further encourages neutrophil migration. After localization to vulnerable vascular beds, neutrophils undergo necroptosis, and form neutrophil extracellular traps (NETs). This process promotes complement activation, and subsequent endothelial damage. Furthermore, NETs facilitate MPO presentation and propagation of the autoimmune response.

phenotypic heterogeneity and relapse prediction. Despite their critical roles in advancing our understanding of diseases, models have also been limited by their lack of consistency between laboratories, making research collaboration and conducting replication studies a significant challenge.

Of note, most animal models of AAV assess the impact of disease on the kidneys. Although renal disease is responsible for a major part of disease burden, other common organ manifestations are largely unstudied.
Different models have each shed light on different aspects of disease pathogenesis. Inspired by the identification of ANCA and its ability to activate neutrophils in vitro, earlier studies confirmed the pathogenicity of ANCA. The roles of priming and activating neutrophils, neutrophil migration to target organs and neutrophil degradation and extracellular trap formation have been investigated. The complex interplay between the adaptive and innate immune systems continues to be explored, including the role of T cells, complement and mast cells. 


\section{ANIMAL MODELS OF MPO-AAV}

In particular, animal models of MPO-AAV have been invaluable, in part due to significant homology with the human equivalent. The autoantigen itself is highly homologous, the pattern of ANCA binding to neutrophils is similar and the effects in the kidney are comparable, with a pauci-immune focal segmental crescentic GN. Table 1 summarizes selected models of MPOANCA associated renal vasculitis.

\section{Passive Transfer of Anti-MPO Antibodies, Splenocytes, or MPO-Specific T Cells Transfer of Anti-MPO Antibodies}

Models centered on passive transfer of MPO-ANCA-like antibodies have been used in several laboratories to elucidate the complex pathogenesis of disease $(15,25,31)$. Antibodies are usually generated by immunizing MPO deficient mice. While these antibodies are similar to MPO-ANCA, they are generated in mice that are not tolerant to $\mathrm{MPO}(15,32)$ and therefore are most accurately described as anti-MPO antibodies. Models based on these principles have been valuable in explaining several areas of the effector response in AAV. These include the role of ANCA, neutrophil priming, activation, migration and adhesion, followed by endothelial injury. Furthermore, targets for potential treatments have been identified and trialed (21).

ANCA were initially identified in patients with segmental necrotising GN in the 1980s (11). While subsequent in vitro studies showed that ANCA can cause neutrophil activation and degranulation $(12,14,33,34)$, the first in vivo animal model data supporting the pathogenicity of ANCA were not published until many years later, when Kobayashi et al. showed enhancement of glomerular injury caused by anti-glomerular basement membrane (GBM) antibodies when co-administered with antiMPO serum (24). Mouse models of anti-MPO GN involving passive transfer of anti-MPO antibodies were subsequently developed. Transfer of anti-MPO IgG, from MPO-immunized

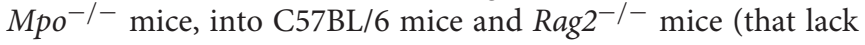
$\mathrm{T}$ and $\mathrm{B}$ lymphocytes) caused focal necrotising and crescentic pauci-immune GN, demonstrating the pathogenicity of ANCA in vivo and its role in acute glomerular injury (15). A key role for neutrophils as effectors in this model was demonstrated by neutrophil depletion that completely protected mice from glomerular histological injury, suggesting that ANCA induced glomerular injury was neutrophil mediated and that neutrophils were a major ANCA target (35).

Whilst passive transfer of anti-MPO antibodies without neutrophil priming has been shown to cause GN (15), disease is usually more severe when pro-inflammatory signals, such as lipopolysaccharide (LPS), are administered around the time of antibody transfer. Administration of LPS shortly after anti-MPO antibody transfer, with subsequent elevation in tumor necrosis factor (TNF) and circulating MPO levels, was shown to result in a significantly greater proportion of glomerular crescents and glomerular necrosis. This effect could be attenuated by TNF blockade (32). Neutrophil numbers, in addition to priming, were shown to be important in later experiments. Daily granulocyte colony stimulating factor (G-CSF) injections, causing an increase in circulating neutrophils, were administered in addition to LPS in the passive transfer model, leading to more severe disease (31). Based on in vitro experiments, the ability for ANCA to activate neutrophils is thought to be dependent on Fc $\gamma$ receptors, in particular Fc $\gamma$ RIIA (36-38). In vivo data supports a regulatory role for Fc $\gamma$ RIIB in ANCA mediated injury, with Fcgr $2 b^{-/-}$ mice pre-treated with LPS and anti-MPO antibodies developing increased glomerular injury compared with Fc $\gamma$ RIIB intact mice (39).

Given the role of complement as a potent mediator in vascular inflammation in other diseases, Xiao et al. hypothesized that despite the paucity of complement deposition in renal biopsies in AAV, complement activation may well be an important player. Xiao et al. showed in vitro that complement is activated after stimulation of human neutrophils with ANCA, via C3a detection (17), with subsequent experiments confirming that this effect was through activation of the C5a receptor (C5aR) (40). C5 deficient mice or mice treated with a neutralizing anti-C5a antibody were protected from glomerular damage after passive transfer of anti-MPO IgG (41). In addition to neutrophil priming, activation of the $\mathrm{C} 5 \mathrm{aR}$ on dendritic cells promotes autoimmunity to MPO (22). A C5aR antagonist CCX168 (avacopan) protected mice expressing human $\mathrm{C} 5 \mathrm{aR}$ from glomerular injury (21), with subsequent translation into human clinical trials of this compound in the treatment of AAV (42). The membrane attack complex does not seem to play a significant role, showing that C5a's effects are via the C5aR (21).

Further work has explored the relative contributions of other complement factors. C3 depletion with Cobra Venom Factor (CVF) prevented GN after passive transfer of anti-MPO IgG or anti-MPO splenocytes (17), though C3aR deficient mice are not protected from glomerular injury after passive transfer of antiMPO IgG (43), and C3aR is not required for neutrophil priming (40). As such, it is conceivable that since C3 is upstream in the complement cascade, its role in neutrophil activation is as a precursor for C5a generation.

The alternative pathway of complement appears to be the dominant pathway in neutrophil activation in experimental AAV. Deficiency of factor $B$, which is specifically involved in alternate pathway activation, protected mice from development of disease. In contrast, mice deficient in $\mathrm{C} 4$, required for activation of the classical and lectin pathways, were not protected (44). Initiation of complement activation appears to be independent of both properdin, which is released by activated neutrophils and can initiate the alternative pathway, and MBL-associated serine protease 2 (MASP-2), which can activate the lectin pathway (41). Properdin deficient mice were not protected from disease after anti-MPO antibody transfer. As such, the initiator of the alternative pathway in AAV remains unknown. Recent in vitro data suggests that NETs may provide a scaffold for complement activation (45), including allowing MPO interaction with Factor $\mathrm{H}$, an important alternative complement pathway regulator (46).

After activation by ANCA, neutrophils are attracted to vulnerable vascular beds, where they degranulate and subsequently cause endothelial damage and disease. Inhibiting neutrophil migration may serve as a promising target for treatment of AAV. Experiments by Summers et al. explored 
TABLE 1 | Selected models of MPO-ANCA associated renal vasculitis.

\begin{tabular}{|c|c|c|c|c|c|}
\hline & Animal & $\begin{array}{l}\text { Severity (t to } \\
+++)^{a}\end{array}$ & $\begin{array}{l}\text { Duration } \\
\text { (effector phase) }\end{array}$ & $\begin{array}{l}\text { Contribution to } \\
\text { knowledge of } \\
\text { pathogenesis }^{b}\end{array}$ & Limitations \\
\hline \multicolumn{6}{|l|}{ EXPERIMENTAL MPO-AAV } \\
\hline Passive transfer & & & & & $\begin{array}{l}\text { No model studies active } \\
\text { autoimmunity to MPO }\end{array}$ \\
\hline $\begin{array}{l}\text { Anti-MPO serum with } \\
\text { anti-GBM Ab (24) }\end{array}$ & Wistar rats & ++ to +++ & $\begin{array}{l}3 \text { or } 15 \mathrm{~h} \text {, or } 14 \\
\text { days }\end{array}$ & $\begin{array}{l}\text { Neutrophil activation is a } \\
\text { prerequisite }\end{array}$ & $\begin{array}{l}\text { Dual hit required } \\
\text { Strong linear lgG deposition }\end{array}$ \\
\hline Transfer of anti-MPO Ab (15) & $\begin{array}{l}\text { C57BL/6 or } \\
\text { Rag2 }^{-/-} \text {mice }\end{array}$ & ++ & 6 days & $\begin{array}{l}\text { Proof of pathogenic role of } \\
\text { anti-MPO Ab and } \\
\text { neutrophils }\end{array}$ & $\begin{array}{l}\text { Not strictly autoimmune } \\
\text { (anti-MPO Ab raised in } \\
\mathrm{Mpo}^{-1-} \text { mice) }\end{array}$ \\
\hline $\begin{array}{l}\text { Transfer of splenocytes from } \\
\text { MPO-immunized } \mathrm{Mpo}^{-/-} \\
\text {mice (15) }\end{array}$ & Rag2-/- mice & ++ & 13 days & $\begin{array}{l}\text { Injury mediated by MPO } \\
\text { specific cells }\end{array}$ & $\begin{array}{l}\text { Some immune complex } \\
\text { deposition } \\
\text { Not strictly autoimmune } \\
\text { Immunodeficient recipients }\end{array}$ \\
\hline $\begin{array}{l}\text { Transfer of MPO intact bone } \\
\text { marrow to MPO-immunized } \\
\mathrm{Mpo}^{-/-} \text {mice (25) }\end{array}$ & $\mathrm{Mpo}^{-1-}$ mice & ++ & 8 weeks & $\begin{array}{l}\text { MPO expression by } \\
\text { leukocytes is required for } \\
\text { anti-MPO Ab effects }\end{array}$ & $\begin{array}{l}\text { Not strictly autoimmune in } \\
\text { the induction of immunity } \\
\text { Requires bone } \\
\text { marrow transplantation }\end{array}$ \\
\hline $\begin{array}{l}\text { Transfer of effector } \\
\text { MPO-specific CD4+(18, 26) } \\
\text { or CD8+ (20) T cells/T cell } \\
\text { clones }\end{array}$ & Rag1-/- mice $^{-1}$ & ++ & 14 days & $\begin{array}{l}\text { MPO-specific CD4+/CD8+ } \\
\text { T cells recognize MPO } \\
\text { planted in the glomerulus, } \\
\text { then effect injury }\end{array}$ & $\begin{array}{l}\text { Anti-MPO Ab have been } \\
\text { used for antigen } \\
\text { deposition/recognition, but } \\
\text { often uses sheep } \\
\text { anti-mouse GBM } \\
\text { Immunodeficient recipients }\end{array}$ \\
\hline \multicolumn{6}{|l|}{ Active autoimmunity } \\
\hline $\begin{array}{l}\text { Active autoimmunity, with } \\
\text { disease trigger: neutrophil } \\
\text { lysosomal enzyme extract } \\
\text { with } \mathrm{H}_{2} \mathrm{O}_{2}(27) \text {, } \\
\text { ischemia/reperfusion (28), } \\
\text { low-dose anti-GBM Ab (29) }\end{array}$ & $\begin{array}{l}\text { Brown Norway } \\
\text { rats }\end{array}$ & ++ to +++ & 10 days & $\begin{array}{l}\text { MPO-ANCA alone may not } \\
\text { be sufficient for disease; } \\
\text { trigger required }\end{array}$ & $\begin{array}{l}\text { Significant IgG and C3 } \\
\text { deposition } \\
\text { Some versions } \\
\text { technically challenging }\end{array}$ \\
\hline $\begin{array}{l}\text { Active autoimmunity in } \\
\text { GN-susceptible rats (30) }\end{array}$ & WKY rats & ++ & 6 weeks & $\begin{array}{l}\text { Loss of tolerance to MPO } \\
\text { after immunization }\end{array}$ & $\begin{array}{l}\text { Rat strain specific } \\
\text { No clear demarcation } \\
\text { between induction of } \\
\text { immunity and } \\
\text { effector responses }\end{array}$ \\
\hline $\begin{array}{l}\text { Active autoimmunity, with } \\
\text { disease trigger (16) }\end{array}$ & C57BL/6 mice & + to ++ & $4-5$ days & $\begin{array}{l}\text { Understanding of steps in } \\
\text { antigen recognition and role } \\
\text { of } \mathrm{T} \text { cells as effectors }\end{array}$ & $\begin{array}{l}\text { Requires trigger } \\
\text { Short term effector phase } \\
\text { due to the development of } \\
\text { active immune responses to } \\
\text { foreign globulin }\end{array}$ \\
\hline
\end{tabular}

${ }^{a}+$, mild; ++ , moderate; +++ severe.

${ }^{b}$ Only initial contribution listed due to space limitations.

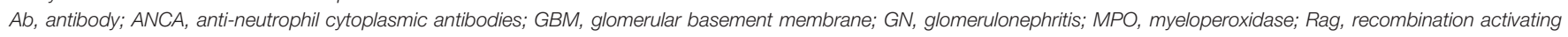
gene; WKY, Wistar Kyoto.

the drivers of neutrophil recruitment to target organs (47). Highly purified LPS, which specifically engages toll-like receptor 4 (TLR4), was associated with increased neutrophil recruitment and functional renal injury when injected with anti-MPO antibodies. TLR4 was predominantly upregulated in glomerular endothelial cells in mice and human cell lines, leading to production of functionally important neutrophil chemoattractants. These effects were mediated by TLR4 expressed both by immune cells and by endothelial cells secreting CXCL1 and CXCL2, the murine homologs of CXCL8 interleukin-8 (IL-8). Subsequent studies in human MPO-ANCA associated GN demonstrated that intrarenal TLR4 expression correlates with the extent of renal injury (48).
Intravital microscopy in both rats and mice after passive transfer of anti-MPO antibodies has enabled a more detailed exploration of interactions between neutrophils and the vascular endothelium. Initial work in this area studied the rat mesenteric post capillary venule (49). CXCL1 was applied topically to the rat mesentery, and rat MPO-ANCA or control antibodies were injected. Topical CXCL1 alone significantly increased endothelial leukocyte adhesion, as well as transmigration that was further enhanced in rats receiving MPO-ANCA after CXCL1. Similar findings were demonstrated in an active immunization model. In both models, changes were not seen in rats with MPO-ANCA that did not receive CXCL1, highlighting the requirement for chemokine involvement in endothelial injury. 
Nolan et al. imaged post capillary venules in the cremaster muscle to assess the response to administration of anti-MPO IgG after pre-treatment with several different cytokines (50). Within minutes of anti-MPO IgG administration, there was reduced leukocyte rolling, enhanced adhesion and increased transmigration across the endothelium. These interactions were $\mathrm{Fc} \gamma$ receptor and $\beta 2$ integrin dependent, and were mediated by cytokines, in particular TNF. Neutrophil migration and adhesion is partly dependent on activation of the kinin system, with genetic deficiency or pharmacological blockade of bradykinin receptor 1 associated with reduced neutrophil surface expression of adhesion molecules and attenuated GN (51).

Post capillary venules are the primary sites of physiological and pathological leukocyte recruitment, but in AAV leukocytes are recruited to capillary beds, particularly glomerular capillaries. The glomerular microvasculature is not only an important target in $\mathrm{AAV}$, but also is unique in the manner by which leukocytes interact with the endothelium $(52,53)$; as such, the effects of anti-MPO antibodies in promoting leukocyte adhesion within the glomerulus itself were examined. In a murine model, antiMPO antibodies were shown to bind to circulating neutrophils, altering adhesion molecules and inducing glomerular leukocyte adhesion via multiple pathways. Mechanisms of adhesion to the glomerular endothelium were affected by the dose of antiMPO antibodies, as well as pre-treatment with LPS to model a pre-existing inflammatory state (53). In the presence of LPS, low dose anti-MPO antibodies induced CD11a/CD18 dependent glomerular neutrophil adhesion, while higher dose antibodies induced $\alpha 4$ integrin dependent adhesion. In these experiments, the same stimuli did not induce leukocyte recruitment to cremasteric post capillary venules, consistent with clinical observations of preferential and often selective renal involvement of glomeruli in AAV. In vivo multiphoton microscopy, with the capacity to image glomerular leukocyte behaviors over time without the risk of endothelial photoactivation, has demonstrated that neutrophils are retained in glomeruli in inflammation, are activated and crawl bidirectionally within the glomerular microvasculature. A single activated neutrophil can crawl at $10 \mu \mathrm{m}$ per minute, a finding that may explain the acute segmental glomerular necrotic lesions seen in AAV (52). This system has also furthered the understanding of the role of complement in neutrophil migration and endothelial injury. C5a was shown to play an important role in MPO-ANCA induced neutrophil retention and activation within the glomerulus (22).

After activation by ANCA and localization to vulnerable vascular beds, neutrophils degranulate but they can also undergo cell death via multiple mechanisms, including neutrophil extracellular trap (NET) formation (known as NETosis) (54). These web-like histone containing structures contain MPO and PR3, and many pro-inflammatory proteins and peptides, some of which are endogenous TLR agonists (55). NETs are released within the microvasulature, where they not only contribute to endothelial injury but also may activate TLRs expressed on resident tissue cells $(48,56)$ and may promote local alternate complement pathway activation (57). They also deposit the autoantigens MPO and PR3 in target tissues, making them potentially able to be presented to effector antigen-specific T cells (58). While mechanistic understanding of NETs has largely been gleaned from in vitro studies $(54,59)$, the functional role of NETs as effectors of injury has also been translated to animal models of AAV. After anti-MPO antibody transfer into mice, enhanced degradation of NETs by administration of DNase I was protective against development of anti-MPO antibody GN (45).

Endothelial cell activation and injury in AAV is mediated by signal transduction pathways, including $N F-\kappa B$ signaling. Activation of NF- $\kappa \mathrm{B}$ by external stimuli allows for migration of NF- $\kappa \mathrm{B}$ into the nucleus, to promote transcription of proinflammatory signals. Choi et al. identified that release of TNF from ANCA-activated neutrophils upregulated NF- $\mathrm{B}$ in endothelial cells, with subsequent IL-8 production. Prophylactic application of immunoliposomes which downregulated endothelial NF-кB was associated with reduced glomerular necrosis (60).

Whilst the role of neutrophils is well-established, monocyte/macrophages have context driven pro-inflammatory roles in immune diseases and play a pathogenic role in AAV. In addition to their general pro-inflammatory properties, primed monocytes also express MPO and PR3 on the cell surface and so plausibly may also play a role in disease $(10,61,62)$. Anti-MPO antibody transfer experiments showed that selective monocyte depletion limited histological but not functional kidney injury (9). Further evidence of the potential role of macrophages in AAV is gleaned from clinical data. Macrophages comprise a significant proportion of leukocytes in kidneys of people with AAV, especially in early disease (63-65). They generate macrophage extracellular traps (METs) and $\sim 25 \%$ of CD68+ macrophages are positive for MPO protein by immunostaining (55). Furthermore elevated urinary soluble CD163, shed by monocytes and macrophages, is strongly associated with active renal vasculitis and has potential as a biomarker to detect renal relapses of AAV (66).

The demonstration of the pathogenicity of ANCA in this model has prompted strategies to alter interactions between ANCA and effector leukocytes. Modification of ANCA IgG glycosylation via IgG hydrolysis limited the clinical and pathological features of GN (67). Interrupting leukocyte signaling has been examined in this and other models (68). A specific inhibitor of p38 mitogen-activated protein kinase (MAPK) administered either before or after transfer of antiMPO antibodies limited glomerular crescent formation without reducing haematuria or proteinuria (69). Dooley et al. trialed EDO-S101, a drug combining the alkylating agent bendamustine with the histone deacetylase inhibitor, vorinostat. Whilst pretreatment with this drug reduced circulating leukocytes, it did not prevent development of GN in the passive transfer model (70).

The effects of factors such as environmental exposures on $\mathrm{AAV}$ are unclear. However, age is a risk factor for AAV development and severity (6). To evaluate the effect of MPOANCA in aged animals, anti-MPO antibodies were passively transferred into recipient aged mice. Aged mice developed more severe GN, with increased circulating and glomerular neutrophils and increased gene expression of pro-inflammatory 
cytokines (71). Although costly, aged mice may better model aged humans and in the future may contribute significantly to the understanding of disease pathogenesis and to studies of new treatments for AAV. Similarly, mice exposed to infections may have an immune system more analogous to adult humans (72, 73), and although these systems currently come with several drawbacks, they may contribute to our understanding in the future.

\section{Transfer of Splenocytes From MPO-Immunized Mice}

As well as transfer of antibodies, splenocytes from MPOimmunized $\mathrm{Mpo}^{-/-}$mice can induce nephritis. Transfer of splenocytes (including both T and B cells) from $\mathrm{Mpo}^{-/-}$mice hyperimmunized with either MPO (or BSA as a control protein) into immunodeficient $R a g 2^{-/-}$mice resulted in detectable serum anti-MPO antibodies within 3 days with dose-dependent necrotising and crescentic GN and renal impairment by day 13, as well as variable involvement of other organs. There was significant glomerular immune complex deposition both in mice receiving anti-MPO splenocytes and control mice which received anti-BSA splenocytes (15).

\section{Transfer of MPO Intact Bone Marrow to MPO-Immunized $\mathrm{Mpo}^{-/-}$Mice}

The pathogenicity of anti-MPO antibodies and the requirement for MPO expression by innate leukocytes was further explored in a bone marrow transfer model where $\mathrm{Mpo}^{-/-}$mice were immunized with MPO, irradiated and reconstituted with bone marrow from MPO intact mice (25). Mice that received wild type bone marrow developed GN with crescent formation in $\sim 30 \%$ of glomeruli. MPO-immunized mice that received $\mathrm{Mpo}^{-/-}$bone marrow remained disease free. Disease could be induced by transfer of anti-MPO antibodies into non-immunized $\mathrm{Mpo}^{-/-}$ mice reconstituted with bone marrow from MPO-intact mice. Collectively, this model confirms the requirement for MPO to be present on leukocytes, most likely neutrophils. Further evidence of the pathogenicity of ANCA was provided in this model by Bontscho et al., with a reduction in renal disease, fewer glomerular neutrophils and lower anti-MPO antibody titres after administration of the proteasome inhibitor bortezomib (or corticosteroids and cyclophosphamide) post bone marrow transplantation (74).

This model has also been used to enhance our understanding of the pathways involved in anti-MPO antibody-neutrophil interactions and injury. One such pathway involves phosphoinositide 3-kinase (PI3K), which controls neutrophil respiratory burst and migration. Bone marrow cells from PI3K $\gamma$-deficient (but MPO intact) mice resulted in only mild glomerular abnormalities. Further, a small molecule inhibitor of PI3K $\gamma$ (AS605250) protected mice from development of GN after transfer of wild type bone marrow (68). Neutrophil serine proteases (NSPs: cathepsin G, neutrophil elastase and proteinase 3) mediate inflammation and injury. To determine their roles, bone marrow transfer studies were undertaken. Mice receiving NSP deficient bone marrow or marrow from mice lacking dipeptidyl peptidase I (DPPI, required for activation of NSPs) were protected from developing crescentic GN, possibly due to disrupted signaling via IL-1 $\beta$ (75). In addition to the passive anti-MPO antibody studies outlined above, this bone marrow transplant model has helped established a role for C5a-C5aR interactions using C5aR deficient mice (40), as well as a role for NETs in the effector phase of MPO-AAV using Receptor-interacting protein kinase-3 (RIPK3) deficient mice (45).

\section{Transfer of Effector CD4+ or CD8+ T Cells}

Passive $\mathrm{T}$ cell transfer studies have defined a role for $\mathrm{CD} 4+$ and CD8+ cells in AAV. Autoreactive CD4+ and CD8+ cells are present in people with AAV (76-79). The obligatory and welldocumented presence of the autoantigen in inflamed tissues in these conditions (due to local myeloid cell release of MPO and PR3) (55) implies a role for T cells as effectors of injury, assuming these antigens can be processed and presented to antigen-specific $\mathrm{T}$ cells locally. Model antigens have been shown to recruit $\mathrm{T}$ cells to glomeruli to cause injury (80), and at least for MPO, a similar process operates. Experimentally, transfer of antigenspecific CD4+ or CD8+ T cells (as clones) induces necrotising GN when MPO is planted in glomeruli $(18,20)$.

Experimentally, MPO or MPO peptides can be deposited in glomeruli in several ways. Early experiments perfused renal arteries with MPO (27). In the context of $\mathrm{T}$ cell transfer studies, MPO has been deposited in glomeruli in three ways. Firstly, injection of low dose heterologous anti-GBM antibodies induces transient neutrophil recruitment with MPO deposition in glomeruli. Secondly passive transfer of anti-MPO antibodies with LPS results in similar deposition of MPO (18). Thirdly, immunogenic MPO peptides can be coupled to a "carrier" monoclonal mouse anti-GBM monoclonal IgG1 antibody (18, 81). The nephritogenicity of the antibody itself is negligible as mouse IgG1 does not fix complement and has low affinity for Fc receptors. The transfer of clones specific for MPO, either effector Th1 CD4+ $\mathrm{T}$ cells or CD8+ cells, to Rag1 ${ }^{-/-}$mice results in severe necrotising GN after MPO is planted in glomeruli. Glomerular injury is mild to minimal after transfer of cells specific to an irrelevant specificity (ovalbumin) (18, 20). Antigen can be presented intravascularly by patrolling monocytes (58) and may also be presented locally by glomerular endothelial cells, while later in disease dendritic cells infiltrate diseased glomeruli in human AAV (82).

\section{Experimental Autoimmune Anti-MPO Disease Induced by Active Immunization With MPO}

Whilst passive transfer experiments have contributed greatly to our understanding of effector mechanisms in AAV, these systems do not include loss of tolerance to MPO (or PR3). In most passive transfer studies, recipients receive fixed doses of antibodies or cells from donor MPO-immunized animals. Thus, tolerance is not broken in recipients and they do not develop active autoimmunity, meaning that fundamental questions relating to loss of tolerance and potential therapies to re-establish tolerance cannot be addressed. As such, active immunization models of disease have been developed in both rats and mice. 


\section{Active Experimental Anti-MPO Disease in Rats}

Immunization of Brown Norway rats with MPO, with subsequent development of MPO-ANCA, is not sufficient for development of disease. However, necrotising crescentic GN in the presence of ANCA has been initiated by causing glomerular endothelial damage either through perfusion with lysosomal extract containing MPO (27), ischemia/reperfusion (28), or a sub-nephritogenic dose of anti-GBM antibodies (also known as "nephrotoxic serum") (29). There are several possible explanations for the increased injury observed by these additional triggers. However, subsequent studies have demonstrated that this enhanced injury is largely due to planting of MPO, as an antigen, within glomerular capillaries and subsequent recognition by effector $\mathrm{T}$ cells $(16,18,20)$. This occurs either by direct localization of MPO (or antigenic MPO peptides), or by transient recruitment of neutrophils that deposit MPO, allowing local recognition of MPO by MPO-specific effector T cells. A variation of these models in rats investigated the role of products released from activated neutrophils, including MPO, in the pathogenicity of MPO-ANCA, especially in the development of ANCA-associated pulmonary disease $(83,84)$.

Active MPO immunization of the GN-susceptible Wistar Kyoto (WKY) rat strain results in loss of tolerance to MPO with ANCA, mild GN and at times pulmonary disease (30). The role of TNF has been explored in this model. Treatment with anti-TNF antibodies 4 weeks after immunization significantly curtailed active AAV, both functionally and pathologically, without affecting MPO-ANCA titres (85). However, administration of TNF did not enhance disease and TNF levels were not different in rats immunized with MPO compared with controls (86). Unfortunately, a human trial of anti-TNF therapy using etanercept were not successful (87), despite anecdotal reporting of its benefit in humans (88). Although not effective in a mouse passive transfer model of disease, treatment with EDO-S101, that combines an alkylating agent with a histone deacetylase inhibitor, limited renal and lung pathology in MPO-immunized WKY rats even when given after disease establishment, suggesting significant effects on active anti-MPO autoimmunity (70). Co-administration of a sub-nephritogenic dose of anti-GBM antibody to WKY rats enhances glomerular crescent formation and albuminuria. This is associated with overexpression of glomerular chemoattractants including CXCL1 and CXCL2, and enhanced neutrophil activation and adherence to endothelial cells (86).

\section{Active Anti-MPO Glomerulonephritis in Mice}

Based on studies in rats in the 1990s (29), an active model of AAV was developed in mice (16). In these models, autoimmunity to MPO is initiated in genetically intact mice, but the MPOANCA that develops is not sufficient in itself to induce disease. GN is triggered by injection of a low dose of sheep anti-mouse glomerular basement membrane (anti-GBM) antibodies that, as in the $\mathrm{T}$ cell transfer models described above, transiently recruits neutrophils to glomeruli (89) with deposition of MPO. When mice are immunized with MPO, moderate injury develops, but immunization with an irrelevant antigen (usually ovalbumin) results in minimal injury mediated only by the anti-GBM antibodies. Initial studies in this model demonstrated that it is dependent on MPO, as $\mathrm{Mpo}^{-/-}$mice did not develop disease despite mounting an immune response to MPO. This outcome confirms that the use of low-dose anti-GBM antibodies can achieve neutrophil influx and MPO deposition with minimal potential confounding injury. CD4 $+\mathrm{T}$ cell depletion in the effector phase markedly attenuated injury, demonstrating the role of effector CD4+ T cells. Furthermore, B cell deficient mice developed similar disease to mice with intact B cells thereby proving the antibody-independent role of $\mathrm{T}$ cells in this model of anti-MPO associated GN. Later experiments further highlighted the role of T-cell mediated injury. GN caused by passive transfer of anti-MPO antibodies into B cell deficient mice was enhanced by pre-immunization with MPO to induce MPO-specific CD4+ $\mathrm{T}$ cells. These effects could be prevented with $\mathrm{T}$ cell depletion (26). Effectively, this active model demonstrated that in the presence of MPO locally in human AAV, most likely via ANCAactivated neutrophil adhesion, effector $\mathrm{T}$ cells mediate injury. In the model, ANCA is bypassed by the use of low dose anti-GBM antibodies to deposit MPO in glomeruli, resulting in an effector response that is akin to a delayed type hypersensitivity reaction.

This model has led to further investigation into the role of T cells in AAV. CD4+ effector T cells, in particular upon differentiation to Th17 cells, mediate production of neutrophil chemoattractants by tissue cells via release of IL-17A (80). After MPO immunization, IL-17A deficient mice were protected from disease, via effects on both neutrophils and macrophages (90). Studies using mice deficient in Th1 or Th17 defining cytokines have shown an initial Th17 dominant lesion followed later by a Th1 dominant outcome, where Th17 defining cytokines were redundant (81). Other types of $\mathrm{T}$ cells have also been implicated, including CD8 $+\mathrm{T}$ cells (20). Unconventional $\gamma \delta$ $\mathrm{T}$ cells, also a source of IL-17A, play a role in glomerular $\mathrm{T}$ cell and neutrophil recruitment. Mice genetically deficient in $\gamma \delta \mathrm{T}$ cells developed less severe disease compared to wild type mice (91).

The role of Fc $\gamma$ RIIB beyond its involvement in neutrophil activation by ANCA was assessed in this $\mathrm{T}$ cell dependent model of disease. Whilst not expressed on $\mathrm{T}$ cells, Fc $\gamma$ RIIB was shown to inhibit $\mathrm{T}$ cell responses via a tonic inhibitory effect on professional antigen presenting cells, with Fc $\gamma$ RIIB deficient mice having increased $\mathrm{CD} 4+\mathrm{T}$ cells, macrophage and neutrophil recruitment to glomeruli, resulting in increased glomerular injury (39). In addition to its effects on $\mathrm{T}$ and $\mathrm{B}$ cell responses, Fc $\gamma$ RIIB is also likely to directly limit the activity of effector macrophages. In an analogous manner, complement plays an important role in disease beyond neutrophil stimulation. C5aR1 modulates development of autoimmunity to MPO, with $\mathrm{C}_{\mathrm{arr}} \mathrm{S}^{-/-}$mice relatively protected from $\mathrm{T}$ cell mediated disease, as dendritic cells lacking the C5aR1 are not able to fully activate anti-MPO $\mathrm{T}$ cells (22). In contrast, the absence of $\mathrm{C} 3 \mathrm{aR}$ did not affect the development of disease in this active model (43).

Given the induction of autoimmunity in this model, it can be used to interrogate mechanisms of loss of tolerance to MPO. Tan et al. determined that the transcription factor autoimmune regulator (AIRE) promotes the expression of MPO in the thymus, 
enabling the deletion of autoreactive anti-MPO $\mathrm{T}$ cells in the thymus (Figure 1A). This work also found that depletion of regulatory $\mathrm{T}$ cells led to more anti-MPO-specific $\mathrm{T}$ cells, higher ANCA titres and more severe GN (92). Mast cells contribute to peripheral tolerance to MPO, through IL-10 mediated effects on regulatory T cells (Figure 1B) (93). Furthermore, autoimmunity and GN can be attenuated by disodium cromoglicate, a mast cell stabilizer (94).

Animal models have been used to discover and define immunodominant MPO T and B cell epitopes. Specifically, three papers have collectively defined an MPO epitope hot spot in a similar region of the MPO heavy chain, with pathogenic CD4+ T cells (mouse studies across several MHC II allomorphs) (18), B cells (human studies with functional murine models) (95) and $\mathrm{CD} 8+\mathrm{T}$ cells (a pathogenic MPO peptide in mice that is likely to also bind to common HLA Class I alleles) (20). The CD4+ $\mathrm{T}$ cell and $\mathrm{B}$ cell epitopes have been validated in human studies (96). As antigen-specific tolerogenic therapies have potential as curative therapies in autoimmune disease $(97,98)$, knowledge of these epitopes has been used in combination with several tolerogenic platforms in AAV, including nasal tolerance (99), injection of MPO peptide loaded apoptotic cells (81), and injection of tolerogenic dendritic cells (100). While the exact type of regulatory cell varies with different strategies, the mechanism of action in each of these three studies is via the generation of MPO-specific T cells that regulate and suppress established anti-MPO autoimmunity. Collectively these studies show proof of concept that using the previous defined immunodominant MPO $\mathrm{T}$ cell epitope can be used in tolerogenic studies, with antigen-specific effects.

Clinical observations have suggested a correlation between infection and AAV (101, 102). There are several potential mechanistic explanations for this association that are not mutually exclusive. One potential explanation involves the engagement of TLRs, expressed on leukocytes or on intrinsic tissue cells, which stimulate immunity and can alter the strength and direction of the immune response. When mice were co-immunized with MPO and TLR ligand, Summers et al. observed enhanced cellular and humoral autoimmunity, compared with mice immunized with MPO alone (103). TLR2 ligands directed Th17 anti-MPO autoimmunity while TLR9 ligands supported Th1 immunity. Infection may also be associated with loss of tolerance to MPO through molecular mimicry. Immunization of mice with a plasmid-encoded peptide with some sequence homology with the $\mathrm{T}$ cell immunodominant MPO epitope, but found only in some strains of Staphylococcus aureus, induced anti-MPO autoimmunity and vasculitis (104).

A variation of models that immunize with MPO was published by Yumura et al. (105) BSA administration induced antiBSA antibodies, which themselves activate neutrophils causing release of MPO, promoting loss of tolerance to MPO and the development of anti-MPO antibodies. Mice developed features of pulmonary disease and severe crescentic GN. Despite pulmonary disease being a common clinical feature in AAV, most animal models are limited to renal manifestations of AAV.

\section{ANIMAL MODELS OF PR3-AAV}

Compared with experimental models of MPO-AAV, consistent animal models of PR3-AAV (summarized in Table 2) have been difficult to establish. There are several possible reasons for this. Compared with MPO, human and mouse PR3 have limited homology of $68 \%$, and the antigenic determinants of human PR3 may not be preserved in mouse PR3 (106). Peripheral blood neutrophil numbers are lower in mice (107) and total white blood cell numbers may be lower compared to humans, depending on mouse strain (108). In contrast to humans, where neutrophils account for up to $70 \%$ of total leukocytes, in commonly used inbred mouse strains (C57BL/6 and 129/Sv) neutrophils account for 7.7 and $14 \%$ of total white blood cells $\left(9-9.4 \times 10^{3} / \mu \mathrm{L}\right)$, respectively (109). Under resting conditions, PR3 is expressed on the plasma membrane in humans through its co-expression with CD177, via a hydrophobic patch on PR3 (110). Murine PR3 lacks this hydrophobic patch, possibly accounting for why PR3 is not strongly expressed on the mouse neutrophil surface, especially in the resting state (111). This may be significant in the development of murine models of PR3-AAV, as it is believed that expression of PR3 on the neutrophil surface is critical to the pathogenesis of AAV (112). Furthermore, in vitro evidence suggests that PR3ANCA causes neutrophil activation via Fc $\gamma$ RIIA expressed on human neutrophils (37). Importantly, this Fc receptor does not have a murine ortholog (113), which may contribute to the inability of PR3-ANCA to activate mouse neutrophils.

In contrast to MPO-AAV, it has been difficult to use PR3-AAV models of disease to confirm unequivocally the pathogenicity of PR3-ANCA in vivo. Passive transfer of human PR3-ANCA from patients with active vasculitis into $\mathrm{BALB} / \mathrm{c}$ wild type mice led to development of mouse ANCA. After some months many mice developed respiratory inflammation, and diffuse immunoglobulin deposition in the glomeruli, as opposed to the classical pauci-immune GN found in humans with PR3AAV $(114,115)$. Subsequent studies passively transferred mouse anti-PR3 antibodies. PR3 antibodies raised in mPR3/neutrophil elastase (mNE) double-deficient mice and passively transferred to wild type mice were not able to induce vasculitis (116). Similarly, anti-PR3 antibodies from rats immunized with chimeric human/mouse PR3 were transferred into wild type mice. Despite high titres of PR3-ANCA, the mice did not develop clinical or histological features of vasculitis (117).

The presence of PR3-ANCA in itself did not cause disease in non-obese diabetic (NOD) mice, which develop spontaneous autoimmune disease. However, splenocyte transfer from these mice into NOD-severe combined immunodeficiency (NODSCID) mice caused crescentic GN and death. In contrast, splenocytes transferred into $\mathrm{Rag}^{-/-}$mice did not develop vasculitis. These experiments imply a significant role for the regulatory immune response in maintaining tolerance and limiting effector responses in PR3-AAV (118).

To overcome species-specific differences in PR3 structure and of Fc receptors, Little et al. transferred PR3-ANCA into mice with a humanized immune system. Irradiated NODSCID-Il $2 r \gamma^{-1-}$ mice were immune reconstituted with human 
hematopoietic stem cells. Passive transfer of human PR3ANCA caused pauci-immune proliferative GN, and histological evidence of pulmonary vasculitis (119), providing the strongest in vivo experimental evidence to date for the pathogenicity of PR3-ANCA.

The latest attempts to overcome species differences and develop a representative murine model of PR3-AAV have involved mice that express human PR3. Mice with podocytes that express human PR3 (under a podocin promoter) did not develop disease after injection with anti-PR3 antibodies (120), perhaps due to a lack of access of the antibodies to the antigen that was expressed extravascularly on podocytes. A double-transgenic approach produced mice with human PR3 in neutrophils along with its co-receptor CD177. Vasculitis could not be induced through passive transfer of anti-PR3 antibodies, possibly because the mice may have been unable to process human pro-PR3 into mature PR3 (121). A third transgenic approach by Martin et al. generated mice expressing the mature form of human PR3, which appeared to be enzymatically active. In a model of zymosan-induced peritonitis, the presence of the hPR 3 transgene increased neutrophil accumulation and enhanced neutrophil survival compared to PR3 wild type controls (122). Studies in experimental AAV using this mouse are yet to be reported.

\section{OTHER MODELS OF AAV}

These models are summarized in Table 2.

\section{Models of ANCA-Associated Pulmonary Vasculitis}

Most animal models of AAV use glomerular disease as the primary endpoint. However, several animal models of pulmonary disease have been designed. Focal pulmonary hemorrhage and granuloma formation were identified in MPO-immunized Brown Norway rats 7 and 14 days after intravenous infusion of human neutrophil lysosomal extract and hydrogen peroxide (84). These changes were accompanied by haemorrhagic lesions within the intestines. Of note, granuloma formation is more closely associated with PR3-AAV, rather than MPO-AAV. A variation of this model explored the role of ANCA in the lung (83). Isolated left lungs of MPO-immunized rats were perfused with a neutrophil lysosomal extract. The isolated left lung displayed inflammatory lesions in both immunized and non-immunized mice, though more extensive in the immunized group; in contrast, there were inflammatory infiltrates also in the right lung only in the presence of anti-MPO antibodies.

Other systems have modeled PR3-AAV associated pulmonary involvement. C-ANCA from patients with GPA was transferred to Wistar rats (123). All animals displayed marked pulmonary vasculitis $24 \mathrm{~h}$ after antibody transfer in a dose-dependent manner [despite the limited homology between human and mouse PR3 (106)], with no disease observed in mice treated with control IgG. Co-perfusion of isolated rat lungs with primed human neutrophils along with murine monoclonal PR3 antibody rapidly caused oedema formation and increased microvascular permeability (124). This was not observed after perfusion of primed neutrophils alone or anti-PR3 antibodies alone, suggesting synergistic roles for anti-PR3 antibodies and neutrophils in pulmonary pathology in AAV.

Pulmonary findings have been described in models that otherwise focus on renal disease. Pulmonary capillaritis developed in 5 of 16 mice after passive transfer of high doses of anti-MPO splenocytes into Rag $2^{-/-}$mice, and in 2 of 6 wild type mice after transfer of anti-MPO antibodies (15). A similar result was also seen in MPO-immunized $\mathrm{Mpo}^{-/-}$mice which were irradiated and reconstituted with bone marrow from wild type mice (25), and after transfer of human PR3-ANCA into irradiated NOD-SCID-Il2 $r \gamma^{-/-}$mice reconstituted with human hematopoietic stem cells (119). Pulmonary lesions were occasionally and inconsistently detected after transfer of MPO peptide-specific CD4+ T cell clones, despite all mice developing glomerulonephritis (18).

\section{Experimental AAV Induced by Autoimmunity to LAMP-2}

Whilst MPO and PR3 are the most common antigenic targets of ANCA, other neutrophil proteins have been identified, including lysosome-associated membrane protein-2 (LAMP-2). Autoantibodies to LAMP-2 have been detected in humans, and were detectable in WKY rats after immunization with LAMP2; these antibodies induced acute focal necrotising GN on transfer (125). The bacterial adhesin FimH contains a sequence with strong homology to the immunogenic epitope of LAMP2 (with eight of the nine amino acids identical). Immunization with FimH induced anti-LAMP-2 antibodies and pauci-immune GN. It was proposed that autoimmunity to LAMP-2 was due to molecular mimicry, potentially explaining the temporal relationship between bacterial infection and AAV. The authors hypothesized that antibodies to LAMP-2 may alter presentation by neutrophils of cytoplasmic antigens, facilitating generation of autoantibodies to MPO or PR3. The results of these animal experiments were not replicated by another research group (129), though anti-LAMP-2 antibodies were found in European AAV cohorts $(130,131)$.

\section{ANCA and Disease in Lupus Prone Mice}

Clinically, ANCA can be detected in some patients with systemic lupus erythematosus (SLE) $(132,133)$, and recent observations suggest that this is associated with a more vasculitic renal phenotype (134). Similarly, some mouse strains that develop systemic autoimmunity also have perinuclear ANCA formation and crescentic GN. A proportion of lupus-prone MRL/lpr fas mice develop MPO-ANCA that bind to MPO on the neutrophil surface. These mice exhibit a phenotype with some characteristics of $\operatorname{AAV}(135,136)$. MRL/lpr mice have been further genetically modified to knockout Nos3, in order to investigate the potential for endothelial nitric oxide synthase (eNOS, or NOS3) to inhibit vascular inflammation. Paradoxically, NOS3 deficient mice had accelerated onset and increased incidence of renal vasculitis compared with control MRL/lpr mice (137).

Derived from two lupus prone strains, MRP/lpr and BXSB, and selectively bred for crescent formation, spontaneous crescentic GN forming/Kinjoh (SCG/Kj) mice have more 
TABLE 2 | Selected models of ANCA associated vasculitis (see Table 1 for animal models of MPO-ANCA associated renal vasculitis).

\begin{tabular}{|c|c|c|c|c|c|}
\hline & Animal & $\begin{array}{l}\text { Severity (+ to } \\
+++)^{\mathrm{a}}\end{array}$ & $\begin{array}{l}\text { Duration } \\
\text { (effector phase) }\end{array}$ & $\begin{array}{l}\text { Contribution to knowledge of } \\
\text { pathogenesis }^{\mathbf{b}}\end{array}$ & Limitations \\
\hline \multicolumn{6}{|l|}{ EXPERIMENTAL PR3-AAV } \\
\hline $\begin{array}{l}\text { PR3-specific splenocyte transfer } \\
\text { (118) }\end{array}$ & NOD-SCID mice & ++ to +++ & 20-40 days & $\begin{array}{l}\text { Anti-PR3 B and T cells mediate } \\
\text { injury; role for regulatory immune } \\
\text { response }\end{array}$ & $\begin{array}{l}\text { Poor homology between } \\
\text { human and mouse PR3 }\end{array}$ \\
\hline \multicolumn{6}{|l|}{ PULMONARY DISEASE } \\
\hline $\begin{array}{l}\text { Active anti-MPO autoimmunity } \\
\text { with human neutrophil lysosomal } \\
\text { extract infusion (84) }\end{array}$ & $\begin{array}{l}\text { Brown Norway } \\
\text { rats }\end{array}$ & ++ to +++ & 14 days & $\begin{array}{l}\text { Chronic inflammation and fibrosis } \\
\text { seen at } 14 \text { days }\end{array}$ & $\begin{array}{l}\text { Granuloma formation } \\
\text { unusual in MPO-AAV }\end{array}$ \\
\hline $\begin{array}{l}\text { Passive transfer of human } \\
\text { PR3-ANCA into rats (123) }\end{array}$ & Wistar rats & ++ to +++ & $24 \mathrm{~h}$ & $\begin{array}{l}\text { In vivo evidence of pathogenicity } \\
\text { of PR3-ANCA }\end{array}$ & Not strictly autoimmune \\
\hline $\begin{array}{l}\text { Perfusion of isolated rat lungs } \\
\text { with primed human neutrophils } \\
\text { and monoclonal PR3 Ab (124) }\end{array}$ & $\mathrm{CD}(\mathrm{SD})$ rats & ++ & $3 \mathrm{~h}$ & $\begin{array}{l}\text { Acute lung injury caused by } \\
\text { neutrophil degranulation and free } \\
\text { oxygen radicals }\end{array}$ & $\begin{array}{l}\text { Ex vivo model } \\
\text { Does not model the process } \\
\text { of neutrophil migration to } \\
\text { the lungs in vivo }\end{array}$ \\
\hline \multicolumn{6}{|l|}{ OTHER MODELS } \\
\hline $\begin{array}{l}\text { Passive transfer of LAMP-2 Ab } \\
\text { (125) }\end{array}$ & WKY rats & + to ++ & 5 days & $\begin{array}{l}\text { LAMP- } 2 \text { is an additional target of } \\
\text { ANCA }\end{array}$ & $\begin{array}{l}\text { Not all Ab preparations are } \\
\text { pathogenic }\end{array}$ \\
\hline Immunization with FimH (125) & WKY rats & ++ & 39 days & $\begin{array}{l}\text { Molecular mimicry may underpin } \\
\text { loss of tolerance to LAMP-2 }\end{array}$ & $\begin{array}{l}\text { Antigen processing not } \\
\text { taken into account } \\
\text { No clear demarcation } \\
\text { between induction of } \\
\text { immunity and } \\
\text { effector responses }\end{array}$ \\
\hline $\begin{array}{l}\text { Passive transfer of NET-loaded } \\
\text { DC (59) }\end{array}$ & $\begin{array}{l}\text { BALB/c and } \\
\text { C57BL/6 mice }\end{array}$ & ++ to +++ & 3 months & $\begin{array}{l}\text { NETs may be involved in } \\
\text { development of autoimmunity to } \\
\text { MPO and PR3 }\end{array}$ & $\begin{array}{l}\text { Production of other auto-Ab } \\
\text { in addition to ANCA } \\
\text { Long model, requires } \\
\text { multiple DC infusions }\end{array}$ \\
\hline $\begin{array}{l}\text { Passive transfer of PTU-induced } \\
\text { abnormal NETs, PTU-induced } \\
\text { MPO-ANCA production (127) }\end{array}$ & WKY rats & + & 30 days & $\begin{array}{l}\text { Prolonged MPO exposure via } \\
\text { NETs may participate in loss of } \\
\text { tolerance }\end{array}$ & Mild disease \\
\hline $\begin{array}{l}\text { Nephrotoxic serum nephritis } \\
\text { (128) }\end{array}$ & C57BL/6 mice & +++ & $7-21$ days & Mechanisms of severe nephritis & $\begin{array}{l}\text { Mechanistically different } \\
\text { effectors } \\
\text { No induction of responses } \\
\text { to ANCA antigens or } \\
\text { transfer of specific cells } \\
\text { or Ab }\end{array}$ \\
\hline
\end{tabular}

${ }^{a}+$, mild; ++ , moderate; +++ severe.

${ }^{b}$ Only initial contribution listed due to space limitations.

Ab, antibody; ANCA, anti-neutrophil cytoplasmic antibodies; CD (SD) Cesarean derived (Sprague-Dawley); DC, dendritic cells; LAMP-2, Iysosome-associated membrane protein 2; MPO,

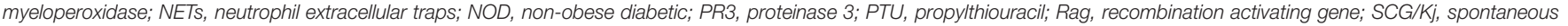
crescentic glomerulonephritis-forming/Kinjoh; SCID, severe combined immunodeficiency; WKY, Wistar Kyoto.

extensive glomerular crescents in all mice (126), though the renal disease may be largely immune complex mediated (138), with development of disease and progression to renal failure significantly delayed by calorie restriction (139). Initial suggestions that neutrophils are required for ANCA-associated GN development were based on experiments in these mice, in 
which increased peripheral neutrophil numbers and glomerular neutrophil infiltration correlated with disease (140). Multiple genetic associations with MPO-ANCA development in SCG/Kj mice have been defined (141). This model has also been used to investigate possible treatments for ANCA-associated GN, including 15-deoxyspergualin $(142,143)$ and omega-3 fatty acid eicosapentaenoic acid (EPA) (144).

Dendritic cell transfer studies have implicated NETs in the development of autoimmunity to MPO and PR3 (59). NETosisprone neutrophils from naïve mice were co-cultured with myeloid dendritic cells ( $\mathrm{mDC}$ ), resulting in $\mathrm{mDC}$ uploading with NET components including MPO. Wild type mice subsequently immunized with NET-loaded dendritic cells (but not dendritic cells exposed to apoptotic or DNAse1 treated neutrophils), lost tolerance to MPO and PR3 and produced ANCA. Furthermore, induction of ANCA was associated with moderate to severe renal injury. However, antibodies to other targets were also produced, including single-stranded and double-stranded DNA, implying a more generalized loss of tolerance consistent with SLE or an SLE-like syndrome.

It is difficult to isolate the effects of anti-MPO and antiPR3 autoreactivity in these models. While ANCA are present, so are other autoantibodies, including anti-double stranded DNA (dsDNA) antibodies. These models are potentially useful as models of vasculitis occurring in the context of SLE with concurrent MPO-ANCA, where in humans segmental necrosis is more likely and in which ANCA may play a role (134).

\section{Drug-Induced Experimental AAV}

The development of MPO-ANCA and clinical features of AAV has been reported in association with many different drugs [review in Gao and Zhao (145)]. The anti-thyroid drug propylthiouracil (PTU) is associated with production of MPOANCA in up to $30 \%$ of patients, with some patients developing MPO-AAV (146). In vitro, incubation of human neutrophils with PTU in the presence of phorbol myristate acetate (PMA) induces NETs. These PTU induced NETs have an abnormal conformation and are more resistant to breakdown by DNase I. It is thought that prolonged MPO exposure on NETs participates in loss of tolerance to MPO, and subsequent ANCA production. Passive transfer of these abnormal NETs into WKY rats caused development of MPO-ANCA and pulmonary capillaritis. In an active model of disease, MPO-ANCA and features of vasculitis developed in rats given PTU in addition to intraperitoneal PMA, with evidence of DNase1-resistant abnormal NET formation. In contrast, mice given only intraperitoneal PMA developed NETs without development of MPO-AAV (127). In a similar model of PTU-induced MPO-ANCA associated vasculitis, BALB/c mice were given PTU; NET formation was attenuated by peptidylarginine deiminase (PAD) inhibition, with lower MPOANCA titres (147).

\section{Autologous Phase Anti-GBM GN (Nephrotoxic Serum Nephritis)}

The most commonly used model of severe and rapidly progressive GN is the autologous phase (accelerated or nonaccelerated) "anti-GBM" model, also known as nephrotoxic serum nephritis (128). This model has been used as proxy for ANCA-associated GN (148). However, while glomerular injury may appear similar histologically, the pathogenesis of this model is substantially different to that of AAV. Glomerular injury in this model is not due to autoimmunity and autoreactivity to MPO is not present $(149,150)$.

The relative contributions of cellular and humoral effectors in this model depend on the strain and species of rodent used, and the nature, timing and dose of the foreign globulin. The initial phase of injury is neutrophil mediated, though unlike ANCAassociated vasculitis, here the heterologous globulin binds to the glomerulus and neutrophils are retained in glomeruli via this in situ immune complex mediated disease $(89,151)$. Subsequently, in non-accelerated iterations of this model, immunity to the foreign globulin (usually raised in sheep or rabbits) as a foreign antigen (not as an autoantigen) develops. Anti-sheep (rabbit) antibodies and/or anti-sheep (rabbit) T cells localize to glomeruli as the antigen (the heterologous globulin) is bound to the glomerulus $(152,153)$. In the accelerated model, immunity to sheep (rabbit) globulin has been induced by priming with the foreign antigen in adjuvant, but injury does not occur until the antigen localizes to the glomerular basement membrane.

Thus, while there may be some similarities in cellular effectors, critical differences in the induction of immunity (including regulatory $\mathrm{T}$ cells), and effector mechanisms mean that this model does not represent ANCA-associated GN. It should not be described as autoimmune and care should be taken in extrapolating results in these models to autoimmune ANCAassociated GN.

\section{DISCUSSION AND CONCLUDING REMARKS}

The use of animal models of AAV, especially combined with careful observational and in vitro human studies has been instrumental in the major advances in our understanding of the pathogenesis of AAV, ranging from the pathogenicity of ANCA, through to elements of loss of tolerance, the role of infection and the participation of cellular immunity. Animal studies on the functional role of complement have led to human trials of new therapies based on complement inhibition. Each of the models used in this search and described in this review has informed us about different aspects of pathogenesis. Table 3 summarizes insights into the pathogenesis of AAV obtained by using animal models and their translational potential.

However, the development of a single, accurate and translatable animal model of ANCA-associated vasculitis has challenged researchers for decades. This disease, and its pathogenesis, is unique in multiple respects. Firstly, it is a systemic autoimmune disease, though there is only one autoantibody clinically detected. ANCAs themselves are unusual in that they cause activation, rather than destruction of the target cell. Effector responses are complex. The autoantigens themselves are both interesting and unusual; whilst MPO and PR3 are present systemically, the disease manifestations are in organs where the autoantigen is not expressed. Clinically, 
TABLE 3 | Influence of animal models on selected elements of the pathogenesis of ANCA-associated vasculitis.

\begin{tabular}{lll}
\hline Observation from humans and in vitro In vivo animal models & Future directions
\end{tabular}

\section{RISK FACTORS}

Incidence increases with age (1)

Anti-MPO antibodies transferred into aged mice associated with more severe disease (71)
PR3 models of disease

Understanding mechanism of risk

PR3-AAV significantly associated with HLA-DP4 (154)

and HLA-DR15 (155)

\section{LOSS OF TOLERANCE}

Association between AAV and infection (102)

Autoimmunity to PR3 may be triggered by exposure to complementary proteins (156)

\section{PATHOGENICITY OF ANCA}

Presence of ANCA in patients with AAV (11) In vitro, capacity of ANCA to induce neutrophil stimulation and degranulation $(12,34)$

Treatment response to autoantibody and B cell depletion NEUTROPHILS AS EFFECTORS

Paucity of immunoglobulin in renal biopsies suggests antibody-independent mechanisms

Number of activated neutrophils in glomeruli is associated with severity of renal disease (13) In vitro, neutrophil degranulation after stimulation with ANCA causes endothelial damage (157)

\section{EFFECT OF CYTOKINES AND CHEMOKINES ON NEUTROPHIL PRIMING, MIGRATION AND ADHESION}

Association between AAV and infection $(102,158)$ In vitro, priming of neutrophils is required for optimum activation by ANCA (159)
Anti-MPO immunity triggered by exposure to bacterial

peptide with MPO sequence homology (104)

Autoimmunity to LAMP-2 developed after immunization with

a homologous peptide from FimH (125)
Passive transfer anti anti-MPO antibodies caused development of GN (15)

Binding of ANCA to neutrophils induces glomerular leukocyte adhesion (53)
Re-induction of tolerance

Presence of ANCA-like antibodies without neutrophil activation is insufficient to cause disease (24) Increased peripheral neutrophil numbers and glomerular neutrophil infiltration correlated with disease (140) Neutrophil depletion protects from disease (35) G-CSF administration exacerbates renal injury (31)
Potential therapies for AAV that de-activate neutrophils
Clarify the role of autoantibody depletion in induction of disease remission

Role for treatments which alter the antibody itself
Passive transfer of anti-MPO antibodies in conjunction with LPS (neutrophil priming) causes more severe disease (32) Engagement of TLR4 on glomerular endothelial cells with highly-purified LPS associated with production of CXCL1 and CXCL2, leading to increased neutrophil migration, adhesion and transmigration (47)

Upregulation of $\beta 2$ integrins, mediated by TNF, is associated with decreased leukocyte rolling and enhanced adhesion (50)

\section{COMPLEMENT IN AAV}

Role of complement first elucidated in animal models, and then confirmed in humans

Patients with AAV have increase plasma levels of alternative pathway activation markers (160) NEUTROPHIL EXTRACELLULAR TRAPS (NETs)

NETs at sites of vascular injury (55)

\section{ROLE OF T CELLS}

Tubulointerstitial and intraglomerular $\mathrm{T}$ cells associated with worse renal injury (55)
C3 depletion prevents GN in mice in passive transfer model (17)

Plays a role in neutrophil retention within the glomerulus and subsequent glomerular injury (22)
After activation by ANCA, neutrophils undergo cell death and develop NETs, which promotes autoimmunity to MPO and propagates glomerular endothelial damage (161)
Further studies of anti-TNF therapies as potential treatment

Studies of inhibiting neutrophil adhesion in AAV

$\begin{array}{ll} & \text { T cells involved in neutrophil chemoattraction through } \\ & \text { production of IL-17A (80) } \\ & \text { Depletion of peripheral regulatory T cells associated with } \\ & \text { more severe disease (93) }\end{array}$

\section{MONOCYTES}

\section{Activated by ANCA (10)}

Presence of monocytes and macrophages in renal biopsies

Soluble CD163 in urine, which is shed by monocytes, is

strongly associated with active renal vasculitis (66)
Role of complement inhibition in disease management e.g. CCX168/avacopan

AAV, ANCA-associated vasculitis; ANCA, anti-neutrophil cytoplasmic antibodies; G-CSF, granulocyte colony stimulating factor; GN, glomerulonephritis; HLA, human leukocyte antigen; LAMP-2, Iysosome-associated membrane protein-2; LPS, lipopolysaccharide; MPO, myeloperoxidase; NCGN, necrotizing crescentic glomerulonephritis; NETs, neutrophil extracellular traps; PR3, proteinase 3; TLR4, toll-like receptor 4; TNF, tumor necrosis factor. 
the disease is heterogeneous, with significant variability in genetic predisposition, environmental risk factors, severity, organ involvement, and risk of relapse.

Given the multi-faceted pathophysiology of AAV, it is not surprising that no single model can recapitulate all aspects of disease. Several disease models are required to comprehensively model and study AAV. Thus far, passive transfer models have proven valuable in studying early effector responses and have resulted in the translation of anti-C5aR therapies into Phase 2 and Phase 3 clinical trials $(21,42,162)$. Further work is necessary to refine and establish animal models that reflect human disease as accurately as possible. Furthermore, the models should be reliably reproducible, tractable and transferrable between laboratories, to promote collaborative research and treatment development. Establishment of such models will facilitate a human-rodenthuman iterative approach which may accelerate understanding, discovery and research translation.

Despite the extensive advancement in knowledge over the past decades, treatment of ANCA-associated vasculitis remains non-specific and toxic. With the likely exception of rituximab, new therapies have not been more efficacious than standard of care, itself associated with significant risks of infection and malignancy. Given the complexity of the pathophysiology, treatment may need to be multi-targeted, requiring collaborative research for development and testing.

Given the emerging knowledge of the differences between PR3-AAV and MPO-AAV, there is a growing need for a model of PR3-AAV. Much can be learnt from the experiences of previous attempts to develop an animal model. The ideal model would likely require human mature PR3 expression in the neutrophil through genetic mutation, manipulation of neutrophil numbers and PR3 membrane expression, as well as consider the importance of Fc $\gamma$ receptors in the ability of ANCA to activate neutrophils. Furthermore, mice transgenic for human immune genes, such as HLA, may be used for understanding the strong genetic associations identified with PR3 (154, 155, $163,164)$ and model key pathways in loss of tolerance and effector responses. Currently there are no published models of eosinophilic granulomatosis with polyangiitis (EGPA). A significant proportion of people with EGPA have MPO-ANCA antibodies and recent GWAS studies suggest a combination of genes relevant both to autoimmunity and to allergy/eosinophil function may be involved in EGPA (165).

In the future, the current animal models need to continue to evolve to address key clinical questions at hand. Examples

\section{REFERENCES}

1. Watts RA, Mahr A, Mohammad AJ, Gatenby P, Basu N, FloresSuarez LF. Classification, epidemiology and clinical subgrouping of antineutrophil cytoplasmic antibody (ANCA)-associated vasculitis. Nephrol Dial Transplant. (2015) 30(Suppl. 1):i14-22. doi: 10.1093/ndt/gfv022

2. Walton EW. Giant-cell granuloma of the respiratory tract (Wegener's granulomatosis). Br Med J. (1958) 2:265-70. doi: 10.1136/bmj.2.5091.265

3. Flossmann O, Berden A, de Groot K, Hagen C, Harper L, Heijl C, et al. Longterm patient survival in ANCA-associated vasculitis. Ann Rheum Dis. (2011) 70:488-94. doi: 10.1136/ard.2010.137778 of how these questions might be addressed are outlined below. ANCA associated vasculitis is largely a disease of older people, and older age is associated with worse renal outcomes and increased mortality, with more complications of treatment (166). The use of aged mice in translational research is increasing, and allows a unique opportunity to more closely mimic human disease (167). Multiple genetic associations with AAV have been identified, especially with regards to antigen presentation (154, 155 , 168), which could be mechanistically explored in HLA transgenic mice. The role of concurrent infections, including but not limited to latent cytomegalovirus infection, in loss of tolerance to ANCA antigens, as well as disease outcomes, needs to be considered $(169,170)$.

At this stage, animal models of MPO-AAV are unable to meaningfully mimic chronic end-organ disease. Clinically, how to best manage AAV in the medium to long term, given its chronic relapsing autoimmunity with tissue injury and damage is a major challenge, and can lead to use of longterm immunosuppression that may or may not be required. Precision medicine would ideally include the capacity to recognize patients at risk of relapse, and reliably identify relapses before end-organ damage ensues. Furthermore, as in many chronic inflammatory diseases, treatments that prevent progressive fibrosis are needed to preserve function after tissue damage mediated by anti-PR3 and anti-MPO autoimmunity.

\section{AUTHOR CONTRIBUTIONS}

LS and AK conducted literature searches, selected relevant articles, planned the format of the article, and wrote the article. $\mathrm{LS}, \mathrm{SH}$, and $\mathrm{AK}$ reviewed, edited, and finalized the article for submission.

\section{FUNDING}

The authors' work in this area was funded by National Health and Medical Research Council (NHMRC) project grants (1128267 and 1104422 to $\mathrm{AK}$ and $\mathrm{SH}$ ) and an NHMRC European Union collaborative research grant (1115805 to AK) as part of the EU Horizon 20/20 RELapses prevENTion in chronic autoimmune disease (RELENT) Consortium. LS was supported by an NHMRC Postgraduate Research Scholarship (1151380) and the Royal Australasian College of Physicians Jacquot NHMRC Award.
4. Jennette JC. Overview of the 2012 revised international Chapel Hill consensus conference nomenclature of vasculitides. Clin Exp Nephrol. (2013) 17:603-6. doi: 10.1007/s10157-013-0869-6

5. Cordova-Sanchez BM, Mejia-Vilet JM, Morales-Buenrostro LE, LoyolaRodriguez G, Uribe-Uribe NO, Correa-Rotter R. Clinical presentation and outcome prediction of clinical, serological, and histopathological classification schemes in ANCA-associated vasculitis with renal involvement. Clin Rheumatol. (2016) 35:1805-16. doi: 10.1007/s10067-0163195-z

6. Salmela A, Tornroth T, Poussa T, Ekstrand A. Prognostic factors for survival and relapse in ANCA-associated vasculitis with renal involvement: 
a clinical long-term follow-up study. Int J Nephrol. (2018) 2018:6369814. doi: 10.1155/2018/6369814

7. Cornec D, Cornec-Le Gall E, Fervenza FC, Specks U. ANCA-associated vasculitis - clinical utility of using ANCA specificity to classify patients. Nat Rev Rheumatol. (2016) 12:570-9. doi: 10.1038/nrrheum.2016.123

8. Hutton HL, Holdsworth SR, Kitching AR. ANCA-associated vasculitis: pathogenesis, models, and preclinical testing. Semin Nephrol. (2017) 37:41835. doi: 10.1016/j.semnephrol.2017.05.016

9. Rousselle A, Kettritz R, Schreiber A. Monocytes promote crescent formation in anti-myeloperoxidase antibody-induced glomerulonephritis. Am J Pathol. (2017) 187:1908-15. doi: 10.1016/j.ajpath.2017.05.003

10. Weidner S, Neupert W, Goppelt-Struebe M, Rupprecht HD. Antineutrophil cytoplasmic antibodies induce human monocytes to produce oxygen radicals in vitro. Arthritis Rheum. (2001) 44:1698-706. doi: 10.1002/15290131(200107)44:7<1698::AID-ART294>3.0.CO;2-J

11. Davies DJ, Moran JE, Niall JF, Ryan GB. Segmental necrotising glomerulonephritis with antineutrophil antibody: possible arbovirus aetiology? Br Med J. (1982) 285:606. doi: 10.1136/bmj.285.6342.606

12. Falk RJ, Terrell RS, Charles LA, Jennette JC. Anti-neutrophil cytoplasmic autoantibodies induce neutrophils to degranulate and produce oxygen radicals in vitro. Proc Natl Acad Sci USA. (1990) 87:4115-9. doi: 10.1073/pnas.87.11.4115

13. Brouwer E, Huitema MG, Mulder AH, Heeringa P, van Goor H, Tervaert JW, et al. Neutrophil activation in vitro and in vivo in Wegener's granulomatosis. Kidney Int. (1994) 45:1120-31. doi: 10.1038/ki.1994.149

14. Keogan MT, Esnault VL, Green AJ, Lockwood CM, Brown DL. Activation of normal neutrophils by anti-neutrophil cytoplasm antibodies. Clin Exp Immunol. (1992) 90:228-34. doi: 10.1111/j.1365-2249.1992.tb07934.x

15. Xiao $\mathrm{H}$, Heeringa $\mathrm{P}$, $\mathrm{Hu} \mathrm{P}$, Liu $\mathrm{Z}$, Zhao $\mathrm{M}$, Aratani $\mathrm{Y}$, et al. Antineutrophil cytoplasmic autoantibodies specific for myeloperoxidase cause glomerulonephritis and vasculitis in mice. J Clin Invest. (2002) 110:955-63. doi: 10.1172/JCI0215918

16. Ruth AJ, Kitching AR, Kwan RY, Odobasic D, Ooi JD, Timoshanko JR, et al. Anti-neutrophil cytoplasmic antibodies and effector CD4+ cells play nonredundant roles in anti-myeloperoxidase crescentic glomerulonephritis. J Am Soc Nephrol. (2006) 17:1940-9. doi: 10.1681/ASN.2006020108

17. Xiao H, Schreiber A, Heeringa P, Falk RJ, Jennette JC. Alternative complement pathway in the pathogenesis of disease mediated by antineutrophil cytoplasmic autoantibodies. Am J Pathol. (2007) 170:52-64. doi: 10.2353/ajpath.2007.060573

18. Ooi JD, Chang J, Hickey MJ, Borza DB, Fugger L, Holdsworth SR, et al. The immunodominant myeloperoxidase T-cell epitope induces local cellmediated injury in antimyeloperoxidase glomerulonephritis. Proc Natl Acad Sci USA. (2012) 109:E2615-24. doi: 10.1073/pnas.1210147109

19. Roth A, Ooi J, Hess J, van Timmeren M, Berg E, Poulton C, et al. ANCA epitope specificity determines pathogenicity, detectability and clinical predictive value. Presse Med. (2013) 42:664. doi: 10.1016/j.lpm.2013.02.033

20. Chang J, Eggenhuizen P, O'Sullivan KM, Alikhan MA, Holdsworth SR, Ooi JD, et al. CD8 $+\mathrm{T}$ cells effect glomerular injury in experimental anti-myeloperoxidase GN. J Am Soc Nephrol. (2017) 28:47-55. doi: 10.1681/ASN.2015121356

21. Xiao H, Dairaghi DJ, Powers JP, Ertl LS, Baumgart T, Wang Y, et al. C5a receptor (CD88) blockade protects against MPO-ANCA GN. J Am Soc Nephrol. (2014) 25:225-31. doi: 10.1681/ASN.2013020143

22. Dick J, Gan PY, Ford SL, Odobasic D, Alikhan MA, Loosen SH, et al. C5a receptor 1 promotes autoimmunity, neutrophil dysfunction and injury in experimental anti-myeloperoxidase glomerulonephritis. Kidney Int. (2018) 93:615-25. doi: 10.1016/j.kint.2017.09.018

23. Hilhorst M, van Paassen P, Tervaert JW, Limburg Renal R. Proteinase 3-ANCA vasculitis versus myeloperoxidase-ANCA vasculitis. J Am Soc Nephrol. (2015) 26:2314-27. doi: 10.1681/ASN.2014090903

24. Kobayashi K, Shibata T, Sugisaki T. Aggravation of rat nephrotoxic serum nephritis by anti-myeloperoxidase antibodies. Kidney Int. (1995) 47:454-63. doi: 10.1038/ki.1995.58

25. Schreiber A, Xiao H, Falk RJ, Jennette JC. Bone marrow-derived cells are sufficient and necessary targets to mediate glomerulonephritis and vasculitis induced by anti-myeloperoxidase antibodies. J Am Soc Nephrol. (2006) 17:3355-64. doi: 10.1681/ASN.2006070718
26. Gan PY, Holdsworth SR, Kitching AR, Ooi JD. Myeloperoxidase (MPO)specific CD4+ T cells contribute to MPO-anti-neutrophil cytoplasmic antibody (ANCA) associated glomerulonephritis. Cell Immunol. (2013) 282:21-7. doi: 10.1016/j.cellimm.2013.04.007

27. Brouwer E, Huitema MG, Klok PA, de Weerd H, Tervaert JW, Weening JJ, et al. Antimyeloperoxidase-associated proliferative glomerulonephritis: an animal model. J Exp Med. (1993) 177:905-14. doi: 10.1084/jem.177.4.905

28. Brouwer E, Klok PA, Huitema MG, Weening JJ, Kallenberg CG. Renal ischemia/reperfusion injury contributes to renal damage in experimental anti-myeloperoxidase-associated proliferative glomerulonephritis. Kidney Int. (1995) 47:1121-9. doi: 10.1038/ki.1995.160

29. Heeringa P, Brouwer E, Klok PA, Huitema MG, van den Born J, Weening JJ, et al. Autoantibodies to myeloperoxidase aggravate mild anti-glomerularbasement-membrane-mediated glomerular injury in the rat. Am J Pathol. (1996) 149:1695-706.

30. Little MA, Smyth L, Salama AD, Mukherjee S, Smith J, Haskard D, et al. Experimental autoimmune vasculitis: an animal model of anti-neutrophil cytoplasmic autoantibody-associated systemic vasculitis. Am J Pathol. (2009) 174:1212-20. doi: 10.2353/ajpath.2009.080458

31. Freeley SJ, Coughlan AM, Popat RJ, Dunn-Walters DK, Robson MG. Granulocyte colony stimulating factor exacerbates antineutrophil cytoplasmic antibody vasculitis. Ann Rheum Dis. (2013) 72:1053-8. doi: 10.1136/annrheumdis-2012-202160

32. Huugen D, Xiao $\mathrm{H}$, van Esch A, Falk RJ, Peutz-Kootstra CJ, Buurman WA, et al. Aggravation of anti-myeloperoxidase antibodyinduced glomerulonephritis by bacterial lipopolysaccharide: role of tumor necrosis factor-alpha. Am J Pathol. (2005) 167:47-58. doi: 10.1016/S0002-9440(10)62952-5

33. Franssen CF, Huitema MG, Muller Kobold AC, Oost-Kort WW, Limburg PC, Tiebosch A, et al. In vitro neutrophil activation by antibodies to proteinase 3 and myeloperoxidase from patients with crescentic glomerulonephritis. J Am Soc Nephrol. (1999) 10:1506-15.

34. Charles LA, Caldas ML, Falk RJ, Terrell RS, Jennette JC. Antibodies against granule proteins activate neutrophils in vitro. J Leukoc Biol. (1991) 50:53946. doi: $10.1002 / \mathrm{jlb} .50 .6 .539$

35. Xiao $H$, Heeringa $P$, Liu $Z$, Huugen $D$, $H u$, Maeda $N$, et al. The role of neutrophils in the induction of glomerulonephritis by anti-myeloperoxidase antibodies. Am J Pathol. (2005) 167:39-45. doi: 10.1016/S0002-9440(10)62951-3

36. Mulder AH, Heeringa P, Brouwer E, Limburg PC, Kallenberg CG. Activation of granulocytes by anti-neutrophil cytoplasmic antibodies (ANCA): a Fc gamma RII-dependent process. Clin Exp Immunol. (1994) 98:270-8. doi: 10.1111/j.1365-2249.1994.tb06137.x

37. Porges AJ, Redecha PB, Kimberly WT, Csernok E, Gross WL, Kimberly RP. Anti-neutrophil cytoplasmic antibodies engage and activate human neutrophils via Fc gamma RIIa. J Immunol. (1994) 153:1271-80.

38. Kettritz R, Jennette JC, Falk RJ. Crosslinking of ANCA-antigens stimulates superoxide release by human neutrophils. J Am Soc Nephrol. (1997) 8:386-94.

39. Ooi JD, Gan PY, Chen T, Eggenhuizen PJ, Chang J, Alikhan $\mathrm{MA}$, et al. FcgammaRIIB regulates T-cell autoreactivity, ANCA production, and neutrophil activation to suppress anti-myeloperoxidase glomerulonephritis. Kidney Int. (2014) 86:1140-9. doi: 10.1038/ki. 2014.189

40. Schreiber A, Xiao H, Jennette JC, Schneider W, Luft FC, Kettritz R. C5a receptor mediates neutrophil activation and ANCAinduced glomerulonephritis. J Am Soc Nephrol. (2009) 20:289-98. doi: 10.1681/ASN.2008050497

41. Freeley SJ, Popat RJ, Parmar K, Kolev M, Hunt BJ, Stover CM, et al. Experimentally-induced anti-myeloperoxidase vasculitis does not require properdin, MASP-2 or bone marrow-derived C5. J Pathol. (2016) 240:61-71. doi: 10.1002/path.4754

42. Jayne DRW, Bruchfeld AN, Harper L, Schaier M, Venning MC, Hamilton P, et al. Randomized trial of c5a receptor inhibitor avacopan in ANCA-associated vasculitis. J Am Soc Nephrol. (2017) 28:2756-67. doi: 10.1681/ASN.2016111179

43. Dick J, Gan PY, Kitching AR, Holdsworth SR. The C3aR promotes macrophage infiltration and regulates ANCA production 
but does not affect glomerular injury in experimental antimyeloperoxidase glomerulonephritis. PLoS ONE. (2018) 13:e0190655. doi: 10.1371/journal.pone. 0190655

44. Huugen D, van Esch A, Xiao H, Peutz-Kootstra CJ, Buurman WA, Tervaert JW, et al. Inhibition of complement factor C5 protects against antimyeloperoxidase antibody-mediated glomerulonephritis in mice. Kidney Int. (2007) 71:646-54. doi: 10.1038/sj.ki.5002103

45. Schreiber A, Rousselle A, Becker JU, von Massenhausen A, Linkermann A, Kettritz R. Necroptosis controls NET generation and mediates complement activation, endothelial damage, and autoimmune vasculitis. Proc Natl Acad Sci U S A. (2017) 114:E9618-25. doi: 10.1073/pnas.1708247114

46. Chen SF, Wang FM, Li ZY, Yu F, Chen M, Zhao MH. Myeloperoxidase influences the complement regulatory activity of complement factor $\mathrm{H}$. Rheumatology. (2018) 57:2213-24. doi: 10.1093/rheumatology/kex529

47. Summers SA, van der Veen BS, O'Sullivan KM, Gan PY, Ooi JD, Heeringa $P$, et al. Intrinsic renal cell and leukocyte-derived TLR4 aggravate experimental anti-MPO glomerulonephritis. Kidney Int. (2010) 78:1263-74. doi: $10.1038 / \mathrm{ki} .2010 .327$

48. O'Sullivan KM, Ford SL, Longano A, Kitching AR, Holdsworth SR. Intrarenal Toll-like receptor 4 and Toll-like receptor 2 expression correlates with injury in antineutrophil cytoplasmic antibodyassociated vasculitis. Am J Physiol Renal Physiol. (2018) 315:F1283-94. doi: 10.1152/ajprenal.00040.2018

49. Little MA, Smyth CL, Yadav R, Ambrose L, Cook HT, Nourshargh S, et al. Antineutrophil cytoplasm antibodies directed against myeloperoxidase augment leukocyte-microvascular interactions in vivo. Blood. (2005) 106:2050-8. doi: 10.1182/blood-2005-03-0921

50. Nolan SL, Kalia N, Nash GB, Kamel D, Heeringa P, Savage CO. Mechanisms of ANCA-mediated leukocyte-endothelial cell interactions in vivo. J Am Soc Nephrol. (2008) 19:973-84. doi: 10.1681/ASN.2007111166

51. Hu P, Su H, Xiao H, Gou SJ, Herrera CA, Alba MA, et al. Kinin B1 receptor is important in the pathogenesis of myeloperoxidase-specific ANCA GN. J Am Soc Nephrol. (2019). doi: 10.1681/ASN.2019010032

52. Devi S, Li A, Westhorpe CL, Lo CY, Abeynaike LD, Snelgrove SL, et al. Multiphoton imaging reveals a new leukocyte recruitment paradigm in the glomerulus. Nat Med. (2013) 19:107-12. doi: 10.1038/nm.3024

53. Kuligowski MP, Kwan RY, Lo C, Wong C, James WG, Bourges D, et al. Antimyeloperoxidase antibodies rapidly induce alpha-4-integrindependent glomerular neutrophil adhesion. Blood. (2009) 113:6485-94. doi: 10.1182/blood-2008-12-192617

54. Kessenbrock K, Krumbholz M, Schonermarck U, Back W, Gross WL, Werb $\mathrm{Z}$, et al. Netting neutrophils in autoimmune small-vessel vasculitis. Nat Med. (2009) 15:623-5. doi: 10.1038/nm.1959

55. O'Sullivan KM, Lo CY, Summers SA, Elgass KD, McMillan PJ, Longano A, et al. Renal participation of myeloperoxidase in antineutrophil cytoplasmic antibody (ANCA)-associated glomerulonephritis. Kidney Int. (2015) 88:1030-46. doi: 10.1038/ki.2015.202

56. Wang H, Gou SJ, Zhao MH, Chen M. The expression of Toll-like receptors 2, 4 and 9 in kidneys of patients with anti-neutrophil cytoplasmic antibody (ANCA)-associated vasculitis. Clin Exp Immunol. (2014) 177:60310. doi: $10.1111 /$ cei. 12365

57. Wang H, Wang C, Zhao MH, Chen M. Neutrophil extracellular traps can activate alternative complement pathways. Clin Exp Immunol. (2015) 181:518-27. doi: 10.1111/cei.12654

58. Westhorpe CLV, Norman MU, Hall P, Snelgrove SL, Finsterbusch $\mathrm{M}$, Li A, et al. Effector $\mathrm{CD} 4(+) \mathrm{T}$ cells recognize intravascular antigen presented by patrolling monocytes. Nat Commun. (2018) 9:747. doi: 10.1038/s41467-018-03181-4

59. Sangaletti S, Tripodo C, Chiodoni C, Guarnotta C, Cappetti B, Casalini P, et al. Neutrophil extracellular traps mediate transfer of cytoplasmic neutrophil antigens to myeloid dendritic cells toward ANCA induction and associated autoimmunity. Blood. (2012) 120:3007-18. doi: 10.1182/blood-2012-03-416156

60. Choi M, Schreiber A, Eulenberg-Gustavus C, Scheidereit C, Kamps J, Kettritz R. Endothelial NF-kappaB blockade abrogates ANCA-Induced GN. J Am Soc Nephrol. (2017) 28:3191-204. doi: 10.1681/ASN.2016060690

61. Ralston DR, Marsh CB, Lowe MP, Wewers MD. Antineutrophil cytoplasmic antibodies induce monocyte IL-8 release. Role of surface proteinase-3, a1-antitrypsin, and Fc $\gamma$ receptors. J Clin Invest. (1997) 100:1416-24. doi: 10.1172/JCI119662

62. Charles LA, Falk RJ, Jennette JC. Reactivity of antineutrophil cytoplasmic autoantibodies with mononuclear phagocytes. J Leukoc Biol. (1992) 51:65-8. doi: $10.1002 / \mathrm{jlb} .51 .1 .65$

63. Zhao L, David MZ, Hyjek E, Chang A, Meehan SM. M2 macrophage infiltrates in the early stages of ANCA-associated pauci-immune necrotizing GN. Clin J Am Soc Nephrol. (2015) 10:54-62. doi: 10.2215/CJN.03230314

64. Weidner S, Carl M, Riess R, Rupprecht HD. Histologic analysis of renal leukocyte infiltration in antineutrophil cytoplasmic antibody-associated vasculitis: importance of monocyte and neutrophil infiltration in tissue damage. Arthritis Rheum. (2004) 50:3651-7. doi: 10.1002/art.20607

65. Cunningham MA, Huang XR, Dowling JP, Tipping PG, Holdsworth SR. Prominence of cell-mediated immunity effectors in "pauci-immune" glomerulonephritis. J Am Soc Nephrol. (1999) 10:499-506.

66. O'Reilly VP, Wong L, Kennedy C, Elliot LA, O'Meachair S, Coughlan AM, et al. Urinary soluble CD163 in active renal vasculitis. J Am Soc Nephrol. (2016) 27:2906-16. doi: 10.1681/ASN.2015050511

67. van Timmeren MM, van der Veen BS, Stegeman CA, Petersen AH, Hellmark T, Collin M, et al. IgG glycan hydrolysis attenuates ANCAmediated glomerulonephritis. J Am Soc Nephrol. (2010) 21:1103-14. doi: 10.1681/ASN.2009090984

68. Schreiber A, Rolle S, Peripelittchenko L, Rademann J, Schneider W, Luft FC, et al. Phosphoinositol 3-kinase-gamma mediates antineutrophil cytoplasmic autoantibody-induced glomerulonephritis. Kidney Int. (2010) 77:118-28. doi: 10.1038/ki.2009.420

69. van der Veen BS, Chen M, Muller R, van Timmeren MM, Petersen AH, Lee $\mathrm{PA}$, et al. Effects of p38 mitogen-activated protein kinase inhibition on antineutrophil cytoplasmic autoantibody pathogenicity in vitro and in vivo. Ann Rheum Dis. (2011) 70:356-65. doi: 10.1136/ard.2010.129106

70. Dooley D, van Timmeren MM, O’Reilly VP, Brady G, O’Brien EC, Fazekas $\mathrm{B}$, et al. Alkylating histone deacetylase inhibitors may have therapeutic value in experimental myeloperoxidase-ANCA vasculitis. Kidney Int. (2018) 94:926-36. doi: 10.1016/j.kint.2018.05.028

71. Wang Q, van Timmeren MM, Petersen AH, Yuan J, Moser J, Brouwer E, et al. Age-determined severity of anti-myeloperoxidase autoantibody-mediated glomerulonephritis in mice. Nephrol Dial Transplant. (2017) 32:254-64. doi: $10.1093 / \mathrm{ndt} / \mathrm{gfw} 202$

72. Beura LK, Hamilton SE, Bi K, Schenkel JM, Odumade OA, Casey KA, et al. Normalizing the environment recapitulates adult human immune traits in laboratory mice. Nature. (2016) 532:512-6. doi: 10.1038/nature17655

73. Kitching AR, Ooi JD. From bench to pet shop to bedside? The environment and immune function in mice. Kidney Int. (2016) 90:1142-3. doi: 10.1016/j.kint.2016.08.017

74. Bontscho J, Schreiber A, Manz RA, Schneider W, Luft FC, Kettritz R. Myeloperoxidase-specific plasma cell depletion by bortezomib protects from anti-neutrophil cytoplasmic autoantibodies-induced glomerulonephritis. $J$ Am Soc Nephrol. (2011) 22:336-48. doi: 10.1681/ASN.2010010034

75. Schreiber A, Pham CT, Hu Y, Schneider W, Luft FC, Kettritz R. Neutrophil serine proteases promote IL-1beta generation and injury in necrotizing crescentic glomerulonephritis. J Am Soc Nephrol. (2012) 23:47082. doi: 10.1681/ASN.2010080892

76. Seta N, Tajima M, Kobayashi S, Kawakami Y, Hashimoto H, Kuwana M. Autoreactive T-cell responses to myeloperoxidase in patients with antineutrophil cytoplasmic antibody-associated vasculitis and in healthy individuals. Mod Rheumatol. (2008) 18:593-600. doi: 10.3109/s10165-008-0109-1

77. Griffith ME, Coulthart A, Pusey CD. T cell responses to myeloperoxidase (MPO) and proteinase 3 (PR3) in patients with systemic vasculitis. Clin Exp Immunol. (1996) 103:253-8. doi: 10.1046/j.1365-2249.1996.d01-629.x

78. Nogueira E, Hamour S, Sawant D, Henderson S, Mansfield N, Chavele KM, et al. Serum IL-17 and IL-23 levels and autoantigen-specific Th17 cells are elevated in patients with ANCA-associated vasculitis. Nephrol Dial Transplant. (2010) 25:2209-17. doi: 10.1093/ndt/gfp783

79. Brouwer E, Stegeman CA, Huitema MG, Limburg PC, Kallenberg CG. $\mathrm{T}$ cell reactivity to proteinase 3 and myeloperoxidase in patients with Wegener's granulomatosis (WG). Clin Exp Immunol. (1994) 98:448-53. doi: 10.1111/j.1365-2249.1994.tb05511.x 
80. Summers SA, Steinmetz OM, Li M, Kausman JY, Semple T, Edgtton KL, et al. Th1 and Th17 cells induce proliferative glomerulonephritis. J Am Soc Nephrol. (2009) 20:2518-24. doi: 10.1681/ASN.2009030337

81. Gan PY, Chan A, Ooi JD, Dick J, Nagai K, O'Sullivan KM, et al. Biologicals targeting $\mathrm{T}$ helper cell subset differentiating cytokines are effective in the treatment of murine anti-myeloperoxidase glomerulonephritis. Kidney Int. (2019) 96:1121-33. doi: 10.1016/j.kint.2019.05.012

82. Wilde B, van Paassen P, Damoiseaux J, Heerings-Rewinkel P, van Rie $\mathrm{H}$, Witzke O, et al. Dendritic cells in renal biopsies of patients with ANCA-associated vasculitis. Nephrol Dial Transplant. (2009) 24:2151-6. doi: 10.1093/ndt/gfp019

83. Foucher P, Heeringa P, Petersen AH, Huitema MG, Brouwer E, Tervaert JW, et al. Antimyeloperoxidase-associated lung disease. An experimental model. Am J Respir Crit Care Med. (1999) 160:987-94. doi: 10.1164/ajrccm.160.3.9807139

84. Heeringa P, Foucher P, Klok PA, Huitema MG, Tervaert JW, Weening JJ, et al. Systemic injection of products of activated neutrophils and $\mathrm{H} 2 \mathrm{O} 2$ in myeloperoxidase-immunized rats leads to necrotizing vasculitis in the lungs and gut. Am J Pathol. (1997) 151:131-40.

85. Little MA, Bhangal G, Smyth CL, Nakada MT, Cook HT, Nourshargh S, et al. Therapeutic effect of anti-TNF-alpha antibodies in an experimental model of anti-neutrophil cytoplasm antibody-associated systemic vasculitis. J Am Soc Nephrol. (2006) 17:160-9. doi: 10.1681/ASN.2005060616

86. Kanzaki G, Nagasaka S, Higo S, Kajimoto Y, Kanemitsu T, Aoki M, et al. Impact of anti-glomerular basement membrane antibodies and glomerular neutrophil activation on glomerulonephritis in experimental myeloperoxidase-antineutrophil cytoplasmic antibody vasculitis. Nephrol Dial Transplant. (2016) 31:574-85. doi: 10.1093/ndt/gfv384

87. Wegener's Granulomatosis Etanercept Trial (WGET) Research Group. Etanercept plus standard therapy for Wegener's granulomatosis. $N$ Engl J Med. (2005) 352:351-61. doi: 10.1056/NEJMoa041884

88. McAdoo SP, Pusey CD. Is there a role for TNF $\alpha$ blockade in ANCAassociated vasculitis and glomerulonephritis? Nephrol Dial Transplant. (2017) 32(Suppl. 1):i80-8. doi: 10.1093/ndt/gfw361

89. Kitching AR, Ru Huang X, Turner AL, Tipping PG, Dunn AR, Holdsworth SR. The requirement for granulocyte-macrophage colony-stimulating factor and granulocyte colony-stimulating factor in leukocyte-mediated immune glomerular injury. J Am Soc Nephrol. (2002) 13:350-8.

90. Gan PY, Steinmetz OM, Tan DS, O’Sullivan KM, Ooi JD, Iwakura Y, et al. Th17 cells promote autoimmune anti-myeloperoxidase glomerulonephritis. J Am Soc Nephrol. (2010) 21:925-31. doi: 10.1681/ASN.2009070763

91. Gan PY, Fujita T, Ooi JD, Alikhan MA, Dick J, Shim R, et al. Pathogenic role for gammadelta $\mathrm{T}$ Cells in autoimmune antimyeloperoxidase glomerulonephritis. J Immunol. (2017) 199:3042-50. doi: 10.4049/jimmunol.1602025

92. Tan DS, Gan PY, O'Sullivan KM, Hammett MV, Summers SA, Ooi JD, et al. Thymic deletion and regulatory T cells prevent antimyeloperoxidase GN. J Am Soc Nephrol. (2013) 24:573-85. doi: 10.1681/ASN.2012090898

93. Gan PY, Summers SA, Ooi JD, O'Sullivan KM, Tan DS, Muljadi RC, et al. Mast cells contribute to peripheral tolerance and attenuate autoimmune vasculitis. J Am Soc Nephrol. (2012) 23:1955-66. doi: 10.1681/ASN.2012060572

94. Gan PY, O'Sullivan KM, Ooi JD, Alikhan MA, Odobasic D, Summers $\mathrm{SA}$, et al. Mast cell stabilization ameliorates autoimmune antimyeloperoxidase glomerulonephritis. J Am Soc Nephrol. (2016) 27:1321-33. doi: 10.1681/ASN.2014090906

95. Roth AJ, Ooi JD, Hess JJ, van Timmeren MM, Berg EA, Poulton CE, et al. Epitope specificity determines pathogenicity and detectability in ANCA-associated vasculitis. J Clin Invest. (2013) 123:1773-83. doi: 10.1172/JCI65292

96. Free ME, Stember KG, Hess JJ, McInnis EA, Lardinois O, Hogan SL, et al. Restricted myeloperoxidase epitopes drive the adaptive immune response in MPO-ANCA vasculitis. J Autoimmun. (2019) 106:102306. doi: 10.1016/j.jaut.2019.102306

97. Benham H, Nel HJ, Law SC, Mehdi AM, Street S, Ramnoruth N, et al. Citrullinated peptide dendritic cell immunotherapy in HLA risk genotypepositive rheumatoid arthritis patients. Sci Transl Med. (2015) 7:290ra87. doi: 10.1126/scitranslmed.aaa9301
98. Capini C, Jaturanpinyo M, Chang HI, Mutalik S, McNally A, Street S, et al. Antigen-specific suppression of inflammatory arthritis using liposomes. $J$ Immunol. (2009) 182:3556-65. doi: 10.4049/jimmunol.0802972

99. Gan PY, Tan DS, Ooi JD, Alikhan MA, Kitching AR, Holdsworth SR. Myeloperoxidase peptide-based nasal tolerance in experimental ANCA-associated GN. J Am Soc Nephrol. (2016) 27:385-91. doi: 10.1681/ASN.2015010089

100. Odobasic D, Oudin V, Ito K, Gan PY, Kitching AR, Holdsworth SR. Tolerogenic dendritic cells attenuate experimental autoimmune antimyeloperoxidase glomerulonephritis. J Am Soc Nephrol. (2019) 30:214057. doi: 10.1681/ASN.2019030236

101. Arimura Y, Minoshima S, Kamiya Y, Tanaka U, Nakabayashi K, Kitamoto K, et al. Serum myeloperoxidase and serum cytokines in anti-myeloperoxidase antibody-associated glomerulonephritis. Clin Nephrol. (1993) 40:256-64.

102. Stegeman CA, Tervaert JW, Sluiter WJ, Manson WL, de Jong PE, Kallenberg CG. Association of chronic nasal carriage of Staphylococcus aureus and higher relapse rates in Wegener granulomatosis. Ann Intern Med. (1994) 120:12-7. doi: 10.7326/0003-4819-120-1-199401010-00003

103. Summers SA, Steinmetz OM, Gan PY, Ooi JD, Odobasic D, Kitching AR, et al. Toll-like receptor 2 induces Th17 myeloperoxidase autoimmunity while Toll-like receptor 9 drives Th1 autoimmunity in murine vasculitis. Arthritis Rheum. (2011) 63:1124-35. doi: 10.1002/art.30208

104. Ooi JD, Jiang JH, Eggenhuizen PJ, Chua LL, van Timmeren M, Loh $\mathrm{KL}$, et al. A plasmid-encoded peptide from Staphylococcus aureus induces anti-myeloperoxidase nephritogenic autoimmunity. Nat Commun. (2019) 10:3392. doi: 10.1038/s41467-019-11255-0

105. Yumura W, Itabashi M, Ishida-Okawara A, Tomizawa K, Yamashita J, Kaneshiro Y, et al. A novel mouse model for MPO-ANCAassociated glomerulonephritis. Microbiol Immunol. (2006) 50:149-57. doi: 10.1111/j.1348-0421.2006.tb03780.x

106. Jenne DE, Fröhlich L, Hummel AM, Specks U. Cloning and functional expression of the murine homologue of proteinase 3: implications for the design of murine models of vasculitis. FEBS Lett. (1997) 408:187-90. doi: 10.1016/S0014-5793(97)00418-3

107. Nagarajan P, Shailendra A, Venkatesan R, Kumar MJM, Majumdar SS, Juyal RC. Sex and strain-related differences in the peripheral blood cell values of mutant mouse strains. Comp Clin Path. (2011) 21:1577-85. doi: 10.1007/s00580-011-1330-4

108. O’Connell KE, Mikkola AM, Stepanek AM, Vernet A, Hall CD, Sun CC, et al. Practical murine hematopathology: a comparative review and implications for research. Comp Med. (2015) 65:96-113.

109. Kile BT, Mason-Garrison CL, Justice MJ. Sex and strain-related differences in the peripheral blood cell values of inbred mouse strains. Mamm Genome. (2003) 14:81-5. doi: 10.1007/s00335-002-2160-0

110. von Vietinghoff S, Tunnemann G, Eulenberg C, Wellner M, Cristina Cardoso M, Luft FC, et al. NB1 mediates surface expression of the ANCA antigen proteinase 3 on human neutrophils. Blood. (2007) 109:4487-93. doi: 10.1182/blood-2006-10-055327

111. Hu N, Westra J, Huitema MG, Bijl M, Brouwer E, Stegeman CA, et al. Coexpression of CD177 and membrane proteinase 3 on neutrophils in antineutrophil cytoplasmic autoantibody-associated systemic vasculitis: anti-proteinase 3-mediated neutrophil activation is independent of the role of CD177-expressing neutrophils. Arthritis Rheum. (2009) 60:1548-57. doi: 10.1002/art.24442

112. Rarok AA, Stegeman CA, Limburg PC, Kallenberg CG. Neutrophil membrane expression of proteinase 3 (PR3) is related to relapse in PR3-ANCA-associated vasculitis. J Am Soc Nephrol. (2002) 13:2232-8. doi: 10.1097/01.ASN.0000028642.26222.00

113. Bruhns P. Properties of mouse and human IgG receptors and their contribution to disease models. Blood. (2012) 119:5640-9. doi: 10.1182/blood-2012-01-380121

114. Blank M, Tomer Y, Stein M, Kopolovic J, Wiik A, Meroni PL, et al. Immunization with anti-neutrophil cytoplasmic antibody (ANCA) induces the production of mouse ANCA and perivascular lymphocyte infiltration. Clin Exp Immunol. (1995) 102:120-30. doi: 10.1111/j.1365-2249.1995.tb06645.x

115. Tomer Y, Gilburd B, Blank M, Lider O, Hershkoviz R, Fishman P, et al. Characterization of biologically active antineutrophil cytoplasmic antibodies 
induced in mice. Pathogenetic role in experimental vasculitis. Arthritis Rheum. (1995) 38:1375-81. doi: 10.1002/art.1780381004

116. Pfister H, Ollert M, Frohlich LF, Quintanilla-Martinez L, Colby TV, Specks $\mathrm{U}$, et al. Antineutrophil cytoplasmic autoantibodies against the murine homolog of proteinase 3 (Wegener autoantigen) are pathogenic in vivo. Blood. (2004) 104:1411-8. doi: 10.1182/blood-2004-01-0267

117. van der Geld YM, Hellmark T, Selga D, Heeringa P, Huitema MG, Limburg PC, et al. Rats and mice immunised with chimeric human/mouse proteinase 3 produce autoantibodies to mouse Pr3 and rat granulocytes. Ann Rheum Dis. (2007) 66:1679-82. doi: 10.1136/ard.2006.064626

118. Primo VC, Marusic S, Franklin CC, Goldmann WH, Achaval CG, Smith RN, et al. Anti-PR3 immune responses induce segmental and necrotizing glomerulonephritis. Clin Exp Immunol. (2010) 159:327-37. doi: 10.1111/j.1365-2249.2009.04072.x

119. Little MA, Al-Ani B, Ren S, Al-Nuaimi H, Leite M Jr, Alpers CE, et al. Antiproteinase 3 anti-neutrophil cytoplasm autoantibodies recapitulate systemic vasculitis in mice with a humanized immune system. PLoS ONE. (2012) 7:e28626. doi: 10.1371/journal.pone. 0028626

120. Relle M, Cash H, Schommers N, Reifenberg K, Galle PR, Schwarting A. PR3 antibodies do not induce renal pathology in a novel PR3-humanized mouse model for Wegener's granulomatosis. Rheumatol Int. (2013) 33:613-22. doi: 10.1007/s00296-012-2406-4

121. Schreiber A, Eulenberg-Gustavus C, Bergmann A, Jerke U, Kettritz R. Lessons from a double-transgenic neutrophil approach to induce antiproteinase 3 antibody-mediated vasculitis in mice. J Leukoc Biol. (2016) 100:1443-52. doi: 10.1189/jlb.5A0116-037R

122. Martin KR, Pederzoli-Ribeil M, Pacreau E, Burgener SS, Dahdah A, Candalh C, et al. Transgenic mice expressing human proteinase 3 exhibit sustained neutrophil-associated peritonitis. J Immunol. (2017) 199:3914-24. doi: 10.4049/jimmunol.1601522

123. Weidebach W, Viana VS, Leon EP, Bueno C, Leme AS, Arantes-Costa $\mathrm{FM}$, et al. C-ANCA-positive IgG fraction from patients with Wegener's granulomatosis induces lung vasculitis in rats. Clin Exp Immunol. (2002) 129:54-60. doi: 10.1046/j.1365-2249.2002.01888.x

124. Hattar K, Oppermann S, Ankele C, Weissmann N, Schermuly RT, Bohle RM, et al. c-ANCA-induced neutrophil-mediated lung injury: a model of acute Wegener's granulomatosis. Eur Respir J. (2010) 36:187-95. doi: 10.1183/09031936.00143308

125. Kain R, Exner M, Brandes R, Ziebermayr R, Cunningham D, Alderson $\mathrm{CA}$, et al. Molecular mimicry in pauci-immune focal necrotizing glomerulonephritis. Nat Med. (2008) 14:1088-96. doi: 10.1038/ nm. 1874

126. Kinjoh K, Kyogoku M, Good RA. Genetic selection for crescent formation yields mouse strain with rapidly progressive glomerulonephritis and small vessel vasculitis. Proc Natl Acad Sci USA. (1993) 90:3413-7. doi: 10.1073/pnas.90.8.3413

127. Nakazawa D, Tomaru U, Suzuki A, Masuda S, Hasegawa R, Kobayashi T, et al. Abnormal conformation and impaired degradation of propylthiouracilinduced neutrophil extracellular traps: implications of disordered neutrophil extracellular traps in a rat model of myeloperoxidase antineutrophil cytoplasmic antibody-associated vasculitis. Arthritis Rheum. (2012) 64:377987. doi: 10.1002/art.34619

128. Odobasic D, Ghali JR, O'Sullivan KM, Holdsworth SR, Kitching AR. Glomerulonephritis induced by heterologous anti-GBM globulin as a planted foreign antigen. Curr Protoc Immunol. (2014) 106:15.26.1-20. doi: 10.1002/0471142735.im1526s106

129. Roth AJ, Brown MC, Smith RN, Badhwar AK, Parente O, Chung H, et al. Anti-LAMP-2 antibodies are not prevalent in patients with antineutrophil cytoplasmic autoantibody glomerulonephritis. J Am Soc Nephrol. (2012) 23:545-55. doi: 10.1681/ASN.2011030273

130. Peschel A, Basu N, Benharkou A, Brandes R, Brown M, Rees AJ, et al. Autoantibodies to hLAMP-2 in ANCA-negative pauciimmune focal necrotizing GN. J Am Soc Nephrol. (2014) 25:455-63. doi: 10.1681/ASN.2013030320

131. Kain R, Tadema H, McKinney EF, Benharkou A, Brandes R, Peschel A, et al. High prevalence of autoantibodies to hLAMP-2 in anti-neutrophil cytoplasmic antibody-associated vasculitis. J Am Soc Nephrol. (2012) 23:55666. doi: 10.1681/ASN.2011090920
132. Chin HJ, Ahn C, Lim CS, Chung HK, Lee JG, Song YW, et al. Clinical implications of antineutrophil cytoplasmic antibody test in lupus nephritis. Am J Nephrol. (2000) 20:57-63. doi: 10.1159/000013557

133. Galeazzi M, Morozzi G, Sebastiani GD, Bellisai F, Marcolongo R, Cervera $\mathrm{R}$, et al. Anti-neutrophil cytoplasmic antibodies in 566 European patients with systemic lupus erythematosus: prevalence, clinical associations and correlation with other autoantibodies. European concerted action on the immunogenetics of SLE. Clin Exp Rheumatol. (1998) 16:541-6.

134. Turner-Stokes T, Wilson HR, Morreale M, Nunes A, Cairns T, Cook HT, et al. Positive antineutrophil cytoplasmic antibody serology in patients with lupus nephritis is associated with distinct histopathologic features on renal biopsy. Kidney Int. (2017) 92:1223-31. doi: 10.1016/j.kint.2017.04.029

135. Harper JM, Thiru S, Lockwood CM, Cooke A. Myeloperoxidase autoantibodies distinguish vasculitis mediated by anti-neutrophil cytoplasm antibodies from immune complex disease in MRL/Mp-lpr/lpr mice: a spontaneous model for human microscopic angiitis. Eur J Immunol. (1998) 28:2217-26.

136. Harper JM, Healey DG, Thiru S, Gordon C, Cook A. Factors involved in the pathogenesis of neutrophilic vasculitis in MRL/Mp-lpr/lpr mice: a model for human microscopic angiitis. Autoimmunity. (1999) 31:133-45. doi: 10.3109/08916939908994057

137. Schoeb TR, Jarmi T, Hicks MJ, Henke S, Zarjou A, Suzuki H, et al. Endothelial nitric oxide synthase inhibits the development of autoimmune-mediated vasculitis in mice. Arthritis Rheum. (2012) 64:411424. doi: $10.1002 /$ art. 37683

138. Neumann I, Birck R, Newman M, Schnulle P, Kriz W, Nemoto $\mathrm{K}$, et al. SCG/Kinjoh mice: a model of ANCA-associated crescentic glomerulonephritis with immune deposits. Kidney Int. (2003) 64:140-8. doi: 10.1046/j.1523-1755.2003.00061.x

139. Cherry, Engelman RW, Wang BY, Kinjoh K, El-Badri NS, Good RA. Calorie restriction delays the crescentic glomerulonephritis of SCG/Kj mice. Proc Soc Exp Biol Med. (1998) 218:218-22. doi: 10.3181/00379727-218-44289

140. Ishida-Okawara A, Ito-Ihara T, Muso E, Ono T, Saiga K, Nemoto K, et al. Neutrophil contribution to the crescentic glomerulonephritis in SCG/Kj mice. Nephrol Dial Transplant. (2004) 19:1708-15. doi: 10.1093/ndt/gfh275

141. Hamano Y, Tsukamoto K, Abe M, Sun GD, Zhang D, Fujii H, et al. Genetic dissection of vasculitis, myeloperoxidase-specific antineutrophil cytoplasmic autoantibody production, and related traits in spontaneous crescentic glomerulonephritis-forming/Kinjoh mice. J Immunol. (2006) 176:3662-73. doi: 10.4049/jimmunol.176.6.3662

142. Birck R, Newman M, Braun C, Neumann I, Nemoto K, Yard B, et al. 15Deoxyspergualin and cyclophosphamide, but not mycophenolate mofetil, prolong survival and attenuate renal disease in a murine model of ANCAassociated crescentic nephritis. Nephrol Dial Transplant. (2006) 21:58-63. doi: $10.1093 /$ ndt/gfi070

143. Tomizawa K, Nagao T, Kusunoki R, Saiga K, Oshima M, Kobayashi K, et al. Reduction of MPO-ANCA epitopes in SCG/Kj mice by 15-deoxyspergualin treatment restricted by IgG2b associated with crescentic glomerulonephritis. Rheumatology. (2010) 49:1245-56. doi: 10.1093/rheumatology/keq087

144. Hirahashi J, Kawahata K, Arita M, Iwamoto R, Hishikawa K, Honda $\mathrm{M}$, et al. Immunomodulation with eicosapentaenoic acid supports the treatment of autoimmune small-vessel vasculitis. Sci Rep. (2014) 4:6406. doi: $10.1038 /$ srep06406

145. Gao Y, Zhao MH. Review article: drug-induced anti-neutrophil cytoplasmic antibody-associated vasculitis. Nephrology. (2009) 14:33-41. doi: 10.1111/j.1440-1797.2009.01100.x

146. Wada N, Mukai M, Kohno M, Notoya A, Ito T, Yoshioka N. Prevalence of serum anti-myeloperoxidase antineutrophil cytoplasmic antibodies (MPOANCA) in patients with Graves' disease treated with propylthiouracil and thiamazole. Endocr J. (2002) 49:329-34. doi: 10.1507/endocr. 49.329

147. Kusunoki Y, Nakazawa D, Shida H, Hattanda F, Miyoshi A, Masuda S, et al. Peptidylarginine deiminase inhibitor suppresses neutrophil extracellular trap formation and MPO-ANCA production. Front Immunol. (2016) 7:227. doi: 10.3389/fimmu.2016.00227

148. Krebs CF, Paust HJ, Krohn S, Koyro T, Brix SR, Riedel JH, et al. Autoimmune renal disease is exacerbated by S1P-receptor-1-dependent intestinal Th17 cell migration to the kidney. Immunity. (2016) 45:1078-92. doi: 10.1016/j.immuni.2016.10.020 
149. Unanue ER, Lee S, Dixon FJ, Feldman JD. Experimental glomerulonephritis. VII. The absence of an autoimmune antikidney response in nephrotoxic serum nephritis. J Exp Med. (1965) 122:565-78. doi: 10.1084/jem.122.3.565

150. Odobasic D, Kitching AR, Semple TJ, Holdsworth SR. Endogenous myeloperoxidase promotes neutrophil-mediated renal injury, but attenuates T cell immunity inducing crescentic glomerulonephritis. J Am Soc Nephrol. (2007) 18:760-70. doi: 10.1681/ASN.2006040375

151. Kuligowski MP, Kitching AR, Hickey MJ. Leukocyte recruitment to the inflamed glomerulus: a critical role for platelet-derived Pselectin in the absence of rolling. J Immunol. (2006) 176:6991-9. doi: 10.4049/jimmunol.176.11.6991

152. Huang XR, Tipping PG, Shuo L, Holdsworth SR. Th1 responsiveness to nephritogenic antigens determines susceptibility to crescentic glomerulonephritis in mice. Kidney Int. (1997) 51:94-103. doi: $10.1038 / \mathrm{ki} .1997 .12$

153. Tarzi RM, Davies KA, Robson MG, Fossati-Jimack L, Saito T, Walport MJ, et al. Nephrotoxic nephritis is mediated by Fcgamma receptors on circulating leukocytes and not intrinsic renal cells. Kidney Int. (2002) 62:2087-96. doi: 10.1046/j.1523-1755.2002.00687.x

154. Xie G, Roshandel D, Sherva R, Monach PA, Lu EY, Kung T, et al. Association of granulomatosis with polyangiitis (Wegener's) with HLA-DPB1*04 and SEMA6A gene variants: evidence from genomewide analysis. Arthritis Rheum. (2013) 65:2457-68. doi: 10.1002/art. 38036

155. Cao Y, Schmitz JL, Yang J, Hogan SL, Bunch D, Hu Y, et al. DRB1*15 allele is a risk factor for PR3-ANCA disease in African Americans. J Am Soc Nephrol. (2011) 22:1161-7. doi: 10.1681/ASN.2010101058

156. Pendergraft WF III, Preston GA, Shah RR, Tropsha A, Carter CW Jr., Falk RJ, et al. Autoimmunity is triggered by cPR-3(105-201), a protein complementary to human autoantigen proteinase-3. Nat Med. (2004) 10:729. doi: $10.1038 / \mathrm{nm} 968$

157. Ewert BH, Jennette JC, Falk RJ. Anti-myeloperoxidase antibodies stimulate neutrophils to damage human endothelial cells. Kidney Int. (1992) 41:37583. doi: $10.1038 / \mathrm{ki} .1992 .52$

158. Salmela A, Rasmussen N, Tervaert JWC, Jayne DRW, Ekstrand A, European Vasculitis Study Group. Chronic nasal Staphylococcus aureus carriage identifies a subset of newly diagnosed granulomatosis with polyangiitis patients with high relapse rate. Rheumatology. (2017) 56:965-72. doi: 10.1093/rheumatology/kex001

159. Yang JJ, Tuttle RH, Hogan SL, Taylor JG, Phillips BD, Falk RJ, et al. Target antigens for anti-neutrophil cytoplasmic autoantibodies (ANCA) are on the surface of primed and apoptotic but not unstimulated neutrophils. Clin Exp Immunol. (2000) 121:165-72. doi: 10.1046/j.1365-2249.2000. 01228.x

160. Gou SJ, Yuan J, Chen M, Yu F, Zhao MH. Circulating complement activation in patients with anti-neutrophil cytoplasmic antibody-associated vasculitis. Kidney Int. (2013) 83:129-37. doi: 10.1038/ki.2012.313
161. Soderberg D, Segelmark M. Neutrophil extracellular traps in ANCA-associated vasculitis. Front Immunol. (2016) 7:256. doi: 10.3389/fimmu.2016.00256

162. Quintana LF, Kronbichler A, Blasco M, Zhao MH, Jayne D. ANCA associated vasculitis: the journey to complement-targeted therapies. Mol Immunol. (2019) 112:394-8. doi: 10.1016/j.molimm.2019.06.018

163. Lyons PA, Rayner TF, Trivedi S, Holle JU, Watts RA, Jayne DR, et al. Genetically distinct subsets within ANCA-associated vasculitis. N Engl J Med. (2012) 367:214-23. doi: 10.1056/NEJMoa1108735

164. Hilhorst M, Arndt F, Joseph Kemna M, Wieczorek S, Donner Y, Wilde B, et al. HLA-DPB1 as a risk factor for relapse in antineutrophil cytoplasmic antibody-associated vasculitis: a cohort study. Arthritis Rheumatol. (2016) 68:1721-30. doi: 10.1002/art.39620

165. Lyons PA, Peters JE, Alberici F, Liley J, Coulson RMR, Astle W, et al. Genome-wide association study of eosinophilic granulomatosis with polyangiitis reveals genomic loci stratified by ANCA status. Nat Commun. (2019) 10:5120. doi: 10.1038/s41467-019-12515-9

166. Harper L, Savage CO. ANCA-associated renal vasculitis at the end of the twentieth century-a disease of older patients. Rheumatology. (2005) 44:495501. doi: 10.1093/rheumatology/keh522

167. Nusser A, Nuber N, Wirz OF, Rolink H, Andersson J, Rolink A. The development of autoimmune features in aging mice is closely associated with alterations of the peripheral CD4(+) T-cell compartment. Eur J Immunol. (2014) 44:2893-902. doi: 10.1002/eji.201344408

168. Merkel PA, Xie G, Monach PA, Ji X, Ciavatta DJ, Byun J, et al. Identification of functional and expression polymorphisms associated with risk for antineutrophil cytoplasmic autoantibody-associated vasculitis. Arthritis Rheumatol. (2017) 69:1054-66. doi: 10.1002/art.40034

169. Morgan MD, Pachnio A, Begum J, Roberts D, Rasmussen N, Neil DA, et al. CD4+CD28- T cell expansion in granulomatosis with polyangiitis (Wegener's) is driven by latent cytomegalovirus infection and is associated with an increased risk of infection and mortality. Arthritis Rheum. (2011) 63:2127-37. doi: 10.1002/art.30366

170. Tao L, Reese TA. Making mouse models that reflect human immune responses. Trends Immunol. (2017) 38:181-93. doi: 10.1016/j.it.2016.12.007

Conflict of Interest: The authors declare that the research was conducted in the absence of any commercial or financial relationships that could be construed as a potential conflict of interest.

Copyright (c) 2020 Shochet, Holdsworth and Kitching. This is an open-access article distributed under the terms of the Creative Commons Attribution License (CC BY). The use, distribution or reproduction in other forums is permitted, provided the original author(s) and the copyright owner(s) are credited and that the original publication in this journal is cited, in accordance with accepted academic practice. No use, distribution or reproduction is permitted which does not comply with these terms. 